\title{
Design of a Regional Venture-Creation Ecosystem by Reusing Components of another Ecosystem
}

\author{
by
}

\section{Abdallah Sunna}

A thesis submitted to the Faculty of Graduate and Postdoctoral Affairs in partial fulfillment of the requirements for the degree of

Master of Applied Science

in

Technology Innovation Management

Carleton University

Ottawa, Ontario

(C) 2016

Abdallah Sunna 


\section{Abstract}

Building a regional ecosystem to support the launch and growth of ventures is complex, time consuming, and risky. Instead of building the venture-creation ecosystem from scratch, individuals and organizations in a region may try to reuse components of an existing venture-creation ecosystem they deem to be successful in another region. This research identifies the defining features of business ecosystems, develops a framework to specify business ecosystems, and produces a design and a plan to build a regional venture-creation ecosystem in Jordan. The design adapts the goals and components of Lead To Win, a venture-creation ecosystem in Ottawa, Canada.

This research is relevant to individuals and organizations building venture-creation regional ecosystems and seeking guidance on how to reuse components from ecosystems in other regions, and to researchers seeking to better understand the configuration required to attain similar goals in different regions. It also guides building a venture-creation ecosystem in Jordan. 


\section{Acknowledgements}

I thank Allah .. the Most Beneficent, the Most Merciful.

I am very grateful to my supervisor and mentor Prof. Tony Bailetti. I don't know how to thank him for the limitless support, knowledge, time, and encouragement he has given me during my master studies and particularly to carry out my thesis work. He has been a great example for me.

I also thank my supervisor Prof. Steven Muegge for the time and knowledge he has given me during my work on this thesis. He is a great example of a professor with academic research rigor. 


\section{Table of Contents}

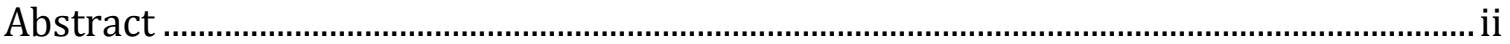

Acknowledgements.................................................................................................................ii

List of Tables.......................................................................................................................vii

List of Appendices ................................................................................................................ viii

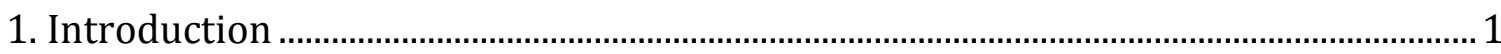



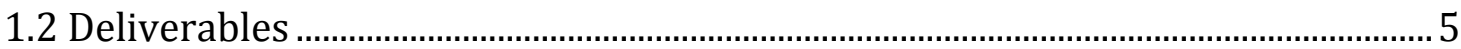

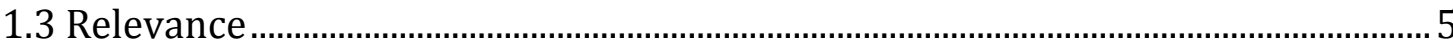

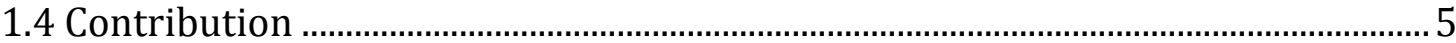

1.5 Organization of the document ...................................................................................... 6

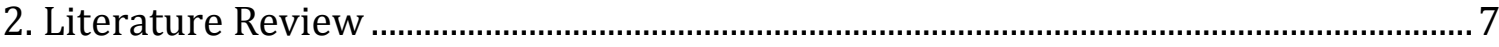

2.1 Literature reviewed .......................................................................................................

2.2 Defining features of business ecosystems ………………………………………... 8

2.2.1 Multi-sided platform perspective …………………………………………... 14

2.2.2 Architecture of participation perspective ...................................................... 17

2.2.3 Biological ecosystem perspective ..................................................................... 20

2.2.4 Complex adaptive system perspective............................................................. 21

2.2.5 Semantic framework perspective ..................................................................... 22

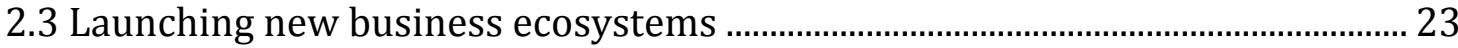

2.3.1 Pragmatic reuse of business ecosystem components...................................... 23

2.3.2 Methods to bring on-board requisite stakeholder groups .............................. 25

2.3.3 Stage of business ecosystem lifecycle ............................................................ 27

2.3.4 Building venture-creation business ecosystems........................................... 27

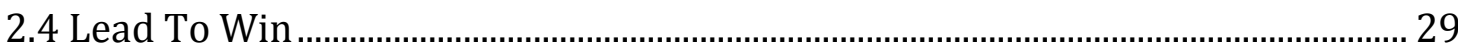

2.4.1 About Lead To Win ......................................................................................... 29

2.4.2 Academic literature on Lead To Win .................................................................. 30

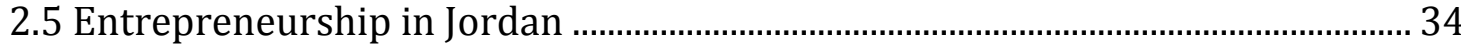

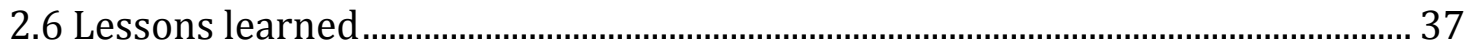




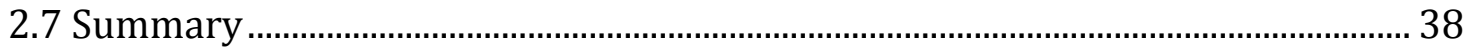

3. Research Method......................................................................................................... 41

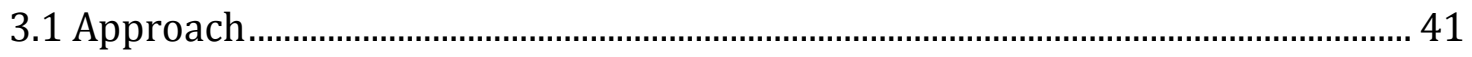

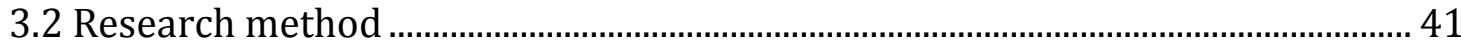

3.2.1 Step 1: Review the literature and develop framework to specify business

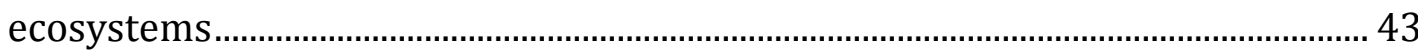

3.2.2 Step 2: Specify the Lead To Win-Ottawa business ecosystem...................... 43

3.2.3 Step 3: Review the literature about entrepreneurship in Jordan and select the components to include in the Lead to Win-Jordan ecosystem.......................... 45

3.2.4 Step 4: Specify the four parts of the Lead To Win-Jordan ecosystem......... 45

3.2.5 Step 5: Develop a plan to implement the new ecosystem Lead To WinJordan. 47

3.2.6 Step 6: Generalize the lessons learned about reusing components of Lead

To Win-Ottawa in a different region................................................................................. 47

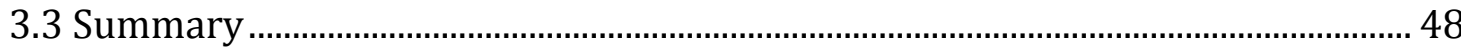

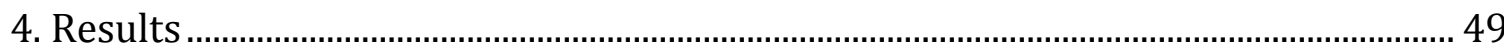

4.1 Framework to specify business ecosystems ......................................................... 49

4.2 Specification of Lead To Win-Ottawa...................................................................... 52

4.2.1 Sides of the Lead To Win-Ottawa business ecosystem.................................... 52

4.2.2 Platform ……………………………………………………………………... 56

4.2.3 Control direct interactions ............................................................................. 58

4.3 Selection of components for pragmatic reuse ........................................................ 62

4.4 Specification of Lead To Win-Jordan......................................................................... 63

4.4.1 Sides of the Lead To Win-Jordan business ecosystem ..................................... 63

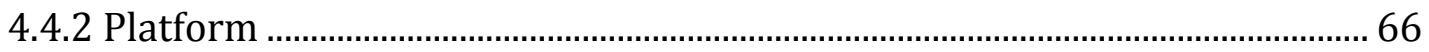

4.4.3 Comparison between LTW-Ottawa and LTW-Jordan ..................................... 68

4.5 Plan to implement the Lead To Win-Jordan venture-creation ecosystem ........ 69

4.6 Method to design and implement a regional venture creation ecosystem that reuses components of another ecosystem ....................................................................... 71

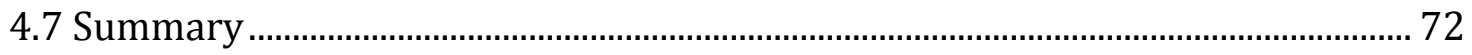

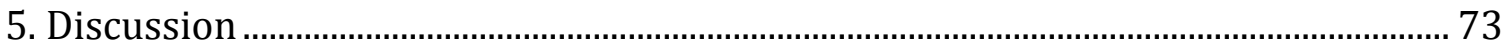


5.1 Toward an integrative model of business ecosystems

5.2 Specific issues that need to be addressed to fill the gap in the extant literature

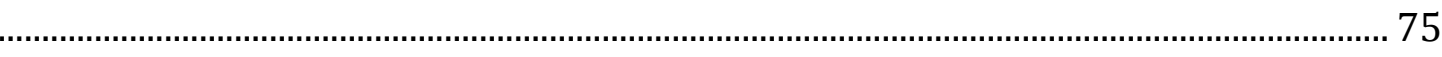

5.3 Comparing results produced in this thesis with those reported by Muegge and Mezen (forthcoming) ..................................................................................................... 76

5.4 Design of Lead To Win-Jordan .............................................................................. 77

5.5 Implementation plan for Lead To Win-Jordan ...................................................... 80

5.6 Method to design and implement a regional venture creation ecosystem that reuses components of another ecosystem ………………………………………...... 80

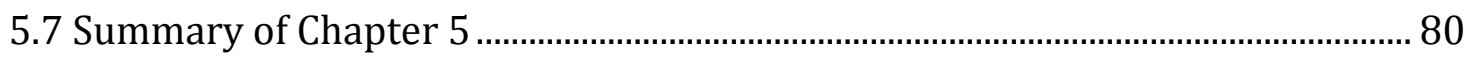

6. Conclusions, Limitations, and Suggestions for Future Research................................. 82

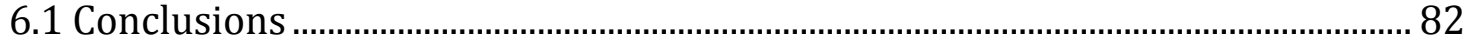

6.2 Limitations ……………………………………………………………….... 84

6.3 Suggestions for future research ........................................................................ 85

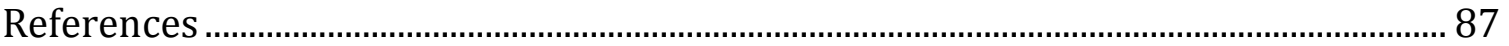




\section{List of Tables}

Table 1: Defining features of a business ecosystem and perspectives used to derive

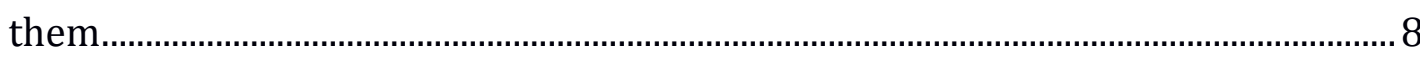

Table 2: Studies that describe the defining features of a business ecosystem by perspective used to derive them ................................................................................. 13

Table 3: Distinct features of a business ecosystem from a multi-sided platform

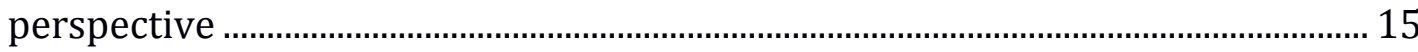

Table 4: Distinct features of a business ecosystem from an architecture of



Table 5: Stakeholder groups, participants and value propositions of Lead To Win.. 31

Table 6: Research method ................................................................................................. 42

Table 7: Framework to specify a business ecosystem using the multi-sided platform

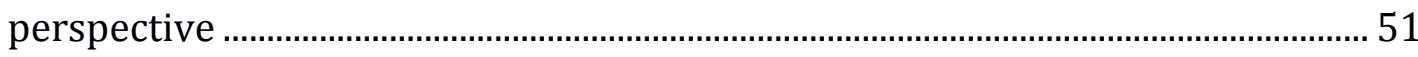

Table 8: Sides of the Lead To Win business ecosystem .................................................... 53

Table 9: Number of components and elements of the Lead To Win platform ............. 57

Table 10: Control over interactions among participants .................................................... 59

Table 11: Number of participants of each side and extent of control over the number

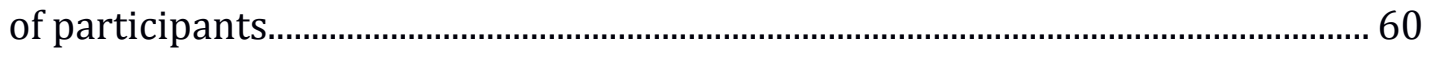

Table 12: Sides of the Lead To Win-Jordan business ecosystem .................................... 64

Table 13: Components and elements of the Lead To Win-Jordan platform .................. 67

Table 14: Lead To Win-Ottawa stakeholders - interviews responses............................ 96

Table 15: Lead To Win-Jordan potential stakeholders - interviews responses ........118 


\section{List of Appendices}

Appendix A: Summary of response from interview with two individuals core to the operations of Lead To Win.......................................................................................... 92

Appendix B: Semi-structured interview protocol for individuals that have knowledge about entrepreneurship in Jordan Appendix C: Summary of responses from interviews with individuals that have knowledge about entrepreneurship in Jordan 104 Appendix D: Lessons learned about entrepreneurship in Jordan 124

Appendix E: Lessons learned about launching multi-sided platforms 


\section{Introduction}

Interest in business ecosystems that create ventures, the researcher's participation in Lead to Win (an ecosystem that exists to support the launch and growth of technology ventures in Ottawa, Canada), and the opportunity to build on recent research within Carleton University's Technology Innovation Management (TIM) program (Mezen, 2014; Muegge \& Mezen, forthcoming) started this research process.

Familiarity with the literature on business ecosystems (Adner \& Kapoor, 2010; Iansiti \& Levien, 2004; Moore, 2006), multi-sided platforms (Boudreau \& Hagiu, 2009; Gawer, 2009, 2014; Hagiu \& Wright, 2015a, b, c) and Lead To Win (Bailetti \& Hudson, 2009; Bailetti, 2010b; Bailetti \& Bot, 2013; Mezen, 2014; Muegge \& Mezen, forthcoming) defined current knowledge. The research question reflects the researcher's views of where the boundary between current knowledge and lack of knowledge about ecosystems to create ventures lies.

The research question is the following: How can components of a regional venture-creation ecosystem be reused to build an ecosystem designed to deliver similar outcomes in another region?

The research question arose out of a perceived knowledge deficit within the literature in business ecosystems. The literature on business ecosystems is large and diverse, covering various aspects of design and operations. However, a recent and comprehensive literature review on business ecosystems (Rong \& Shi, 2015) 
and the researcher's own literature review did not identify a single study on how to use the components of one regional ecosystem to build a new ecosystem in a different region that could deliver similar outcomes. This suggests that the literature on how to build a business ecosystem in a region using components from an ecosystem in a different region is lacking.

The motivation behind this research is twofold. The first motivation is understanding how to reuse the components of Lead To Win to build an ecosystem in Jordan that offers similar outcomes. This research is to guide the creation of a business ecosystem in Jordan to support entrepreneurs launch and grow businesses they own, without taking any equity from them or claiming any intellectual property.

The second motivation for this research is the desire to make a difference in Jordan. Existing initiatives that support entrepreneurs in Jordan are either acceleration programs that invest in ideas to make profits, or workspaces (incubators) without acceleration programs (Wyne, 2015).

Lead To Win was selected as the ecosystem to emulate for three reasons. First, Lead To Win is an exemplar; it ranks among the top ten university business incubators in North America according to UBI Global (2015). Second, Lead To Win was purposely designed to act as a job-creation engine for Canada's capital region (Bailetti \& Hudson, 2009; Bailetti \& Bot, 2013; Muegge \& Mezen, forthcoming). This is consistent with the researcher's aspirations for entrepreneurship in Jordan. Third, because the researcher is participating in Lead To Win as a new venture founder, it 
was easy to access the information and the people required for this research.

In this research, the term "regional" refers to business ecosystems with geographic membership boundaries, where most members are located in a specific geographic location (Muegge, 2011a). The term "reuse" refers here to using again a platform component along with the tacit and explicit knowledge gained designing, operating, and evolving a regional business ecosystem. The term "artifact" refers to an object that is the design product of human intelligence and effort (Simon, 1969, p. 2), that evolves over time "not always or usually with full forethought" (p. 5), may imitate appearances of natural things, and can be characterized in terms of functions, goals, and adaptation (pp. 5-6). A business ecosystem is considered an artifact because it results from interactions between companies and individuals, it imitates an ecological ecosystem in some respects (Moore, 1993; Iansiti \& Levien, 2004; Muegge, 2011a), and can be characterized using various frameworks that include functions, goals, and adaptation (e.g., Muegge, 2011a; Muegge \& Mezen, forthcoming).

This research does not study venture-creation ecosystems in general or their defining features. The study chooses a successful venture-creation ecosystem(Lead To Win in Ottawa, Canada) and examines how its components can be reused to design a venture-creation ecosystem in a different region (Jordan). This research focuses on developing the criteria to select a regional ecosystem's components for pragmatic reuse in different regions. It does not examine how to adapt or integrate ecosystem components in the new region. 
Intercultural differences between Ottawa and Jordan are assumed to be embodied in the i) investments shareholder groups make in the platform that anchors the ecosystem in Jordan, ii) returns these stakeholders expect, iii) components selected for practical reuse, and iv) motivations of the stakeholder groups in Jordan. This research does not focus on identifying what intercultural differences are not incorporated in these four factors.

This research delivers a framework to specify business ecosystems from the perspective of multi-sided platforms. The framework mainly builds on research studies carried out by Hagiu and Wright (2015a, b, c) for the purpose of advancing the theory of the firm. Therefore, the level of abstraction used in this research is similar to the level of abstraction used by Hagiu and Wright (2015a, b, c).

This research also builds on code reuse practices to propose criteria to select regional ecosystem components for pragmatic reuse in different regions.

\subsection{Objective}

The objective of this research is to produce a design and a plan to implement a venture-creation ecosystem in Jordan that can deliver outcomes similar to those delivered by Lead To Win, a venture-creation ecosystem that operates in Ottawa, Ontario, Canada. 


\subsection{Deliverables}

The deliverables of this research include:

1. Framework to specify a business ecosystem

2. Specifications of the Lead To Win-Ottawa and Lead To Win-Jordan venture-creation ecosystems using the framework

3. Plan to implement the Lead To Win-Jordan venture-creation ecosystem

4. Method to design and implement a regional venture creation ecosystem that reuses components of another ecosystem

\subsection{Relevance}

This research is relevant to individuals and organizations responsible for building a system to launch and grow ventures and management researchers. It provides those building venture creation ecosystems with a method to reuse the key components of an ecosystem that operates in another region in their own region. To make progress building an entrepreneurial ecosystem, leaders need practical, if imperfect maps and navigational guidelines (Isenberg, 2010). Likewise, it helps management researchers understand the processes required to attain similar objectives in ecosystems that operate in different regions.

\subsection{Contribution}

This research makes at least two contributions. First, it reduces the subjectivity, time, cost, effort, and risk associated with building a new venture- 
creation business ecosystem. The research contributes a method to specify a venture-creation ecosystem and reuse the components and the associated tacit and explicit knowledge gained designing, operating, and evolving a venture-creation business ecosystem in one region to build an ecosystem that can attain similar outcomes in another region. Transforming tacit knowledge about Lead To Win into explicit knowledge helps its stakeholders understand the link between their contributions and venture- and job-creation, which increases the efficiency of their participation.

The second contribution is that the design of Lead To Win Jordan will help the individuals and organizations that support entrepreneurs in Jordan build a comprehensive and consistent business ecosystem benefiting from the Canadian experience. The implementation plan of Lead To Win Jordan guides the implementation actions, which reduces the experimentation time and the risk of failure.

\subsection{Organization of the document}

This thesis is organized into six chapters. Chapter 1 provides the introduction. Chapter 2 reviews the literature on business ecosystems, Lead To Win, and entrepreneurship in Jordan. Chapter 3 provides the research method. Chapter 4 presents the research results. Chapter 5 discusses the results. Finally, chapter 6 provides the conclusions of the research, identifies the limitations of the research, and suggests future research projects. 


\section{Literature Review}

Chapter 2 is organized into seven sections. Section 2.1 describes the literature reviewed. Section 2.2 identifies the defining features or salient characteristics of business ecosystems found in the literature. Section 2.3 examines the literature on issues that pertain to the launch of new ecosystems. Section 2.4 reviews the literature on Lead To Win. Section 2.5 reviews the literature on entrepreneurship in Jordan. Section 2.6 provides the lessons learned. Finally, Section 2.7 provides a summary of Chapter 2.

\subsection{Literature reviewed}

This chapter reviews the literature on business ecosystems for the purpose of i) identifying the defining features of business ecosystems, ii) examining the launch of new ecosystems, iii) summarizing what is known about the Lead To Win ecosystem, and iv) identifying the challenges of entrepreneurship in Jordan.

By the literature on business ecosystems, the researcher means articles published in the English language by North American and European based academic journals and a few unpublished studies.

The review of the business ecosystem literature found no studies that can be used to select or adapt the components of existing ecosystems into new ecosystems. Therefore, the author also reviewed the recent literature on pragmatic reuse of software components to seek a better understanding of how to operationalize 
component reuse and identify criteria to select components of existing business ecosystems to reuse in new ecosystems.

\subsection{Defining features of business ecosystems}

The literature was first reviewed for the purpose of identifying the studies that examine the defining features of a business ecosystem.

Table 1 provides the 19 studies in the literature that define the features of a business ecosystem. These studies are arranged in the order of the year of their publication. For each set of defining features, Table 1 also provides the perspective the authors used to produce them.

Table 1: Defining features of a business ecosystem and perspectives used to derive them

\begin{tabular}{|c|c|c|c|}
\hline & Defining features & Reference & Perspective \\
\hline 1 & $\begin{array}{l}\text { 1. Modularity in design } \\
\text { 2. Economic organization }\end{array}$ & $\begin{array}{l}\text { Baldwin \& } \\
\text { Clark (2000) }\end{array}$ & $\begin{array}{l}\text { Architecture of } \\
\text { participation }\end{array}$ \\
\hline 2 & $\begin{array}{l}\text { 1. Organizations that use } \\
\text { platform } \\
\text { 2. Platform } \\
\text { 3. Value derived and } \\
\text { contributed by each } \\
\text { stakeholder group } \\
\text { 4. Keystone } \\
\text { 5. Ecosystem health }\end{array}$ & $\begin{array}{l}\text { Iansiti \& Levien } \\
\text { (2004) }\end{array}$ & Biological ecosystem \\
\hline 3 & $\begin{array}{l}\text { 1. Intermediaries that must } \\
\text { adopt focal firm's } \\
\text { innovation }\end{array}$ & Adner (2006) & $\begin{array}{l}\text { Architecture of } \\
\text { participation }\end{array}$ \\
\hline
\end{tabular}




\begin{tabular}{|c|c|c|c|}
\hline & $\begin{array}{l}\text { 2. } \text { Complementors required } \\
\text { for focal firm and } \\
\text { intermediaries to move } \\
\text { innovation forward } \\
\text { 3. Focal firm } \\
\text { 4. Risks due to } \\
\text { interdependence with } \\
\text { complementors and } \\
\text { adoption process }\end{array}$ & & \\
\hline 4 & $\begin{array}{l}\text { 1. Modularity of codebase } \\
\text { 2. Option value }\end{array}$ & $\begin{array}{l}\text { Baldwin \& } \\
\text { Clark (2006) }\end{array}$ & $\begin{array}{l}\text { Architecture of } \\
\text { participation }\end{array}$ \\
\hline 5 & $\begin{array}{l}\text { 1. Collaboration } \\
\text { 2. Space for business } \\
\text { opportunity } \\
\text { 3. Business development } \\
\text { within a space } \\
\text { 4. Firms' innovation } \\
\text { trajectories } \\
\text { 5. Campaigns for ecological } \\
\text { advancement } \\
\text { 6. Infrastructure } \\
\text { 7. Customer feedback } \\
\text { 8. Financing }\end{array}$ & $\begin{array}{l}\text { Moore (2006, } \\
\text { pp. 53-55) }\end{array}$ & $\begin{array}{l}\text { Biological ecosystem } \\
\text { as a new form of } \\
\text { production }\end{array}$ \\
\hline 6 & $\begin{array}{l}\text { 1. Organization of } \\
\text { production } \\
\text { 2. Community governance } \\
\text { 3. Intellectual property }\end{array}$ & $\begin{array}{l}\text { West \& } \\
\text { O'Mahony } \\
(2008)\end{array}$ & $\begin{array}{l}\text { Architecture of } \\
\text { participation }\end{array}$ \\
\hline 7 & $\begin{array}{l}\text { 1. Stakeholder groups } \\
\text { 2. Value derived and } \\
\text { contributed by each } \\
\text { stakeholder group } \\
\text { 3. Keystone }\end{array}$ & $\begin{array}{l}\text { Iyer \& } \\
\text { Davenport } \\
\text { (2008) }\end{array}$ & $\begin{array}{l}\text { Multi-sided platform } \\
\text { as builder enabler }\end{array}$ \\
\hline 8 & $\begin{array}{l}\text { 1. Stakeholder groups } \\
\text { 2. Pricing structure } \\
\text { 3. Instruments, information, } \\
\text { and incentives to perform } \\
\text { regulatory role }\end{array}$ & $\begin{array}{l}\text { Boudreau \& } \\
\text { Hagiu (2009) }\end{array}$ & $\begin{array}{l}\text { Multi-sided platform } \\
\text { as a regulator }\end{array}$ \\
\hline
\end{tabular}




\begin{tabular}{|c|c|c|c|}
\hline & $\begin{array}{l}\text { 4. Platform technology and } \\
\text { design }\end{array}$ & & \\
\hline 9 & $\begin{array}{l}\text { 1. Stakeholder groups of } \\
\text { which suppliers, } \\
\text { complementors, and } \\
\text { customers are core } \\
\text { 2. Focal firm } \\
\text { 3. Components } \\
\text { 4. } \text { Complements }\end{array}$ & $\begin{array}{l}\text { Adner and } \\
\text { Kapoor }(2010)\end{array}$ & $\begin{array}{l}\text { Architecture of } \\
\text { participation }\end{array}$ \\
\hline 10 & $\begin{array}{l}\text { 1. Desired outcomes } \\
\text { 2. Health metrics } \\
\text { 3. Number of stakeholder } \\
\text { groups (i.e., member } \\
\text { classes) } \\
\text { 4. Number of members for } \\
\text { each stakeholder group } \\
\text { 5. Platform } \\
\text { 6. Price structure } \\
\text { 7. Governance }\end{array}$ & $\begin{array}{l}\text { Bailetti } \\
\text { (2010b) }\end{array}$ & $\begin{array}{l}\text { Multi-sided platform } \\
\text { as enabler of } \\
\text { regional economic } \\
\text { outcomes }\end{array}$ \\
\hline 11 & $\begin{array}{l}\text { 1. Technology platform } \\
\text { components } \\
\text { 2. Stakeholder groups } \\
\text { 3. Aspect of platform to } \\
\text { open } \\
\text { 4. Access vs control } \\
\text { decisions }\end{array}$ & $\begin{array}{l}\text { Boudreau } \\
\text { (2010) }\end{array}$ & $\begin{array}{l}\text { Multi-sided platform } \\
\text { as an enabler- } \\
\text { controller } \\
\text { mechanism }\end{array}$ \\
\hline 12 & $\begin{array}{l}\text { 1. Conceptual location of } \\
\text { ecosystem } \\
\text { 2. Anchor point } \\
\text { 3. Membership boundaries } \\
\text { 4. Elements that comprise } \\
\text { the ecosystem }\end{array}$ & $\begin{array}{l}\text { Muegge } \\
\text { (2011a) }\end{array}$ & Semantic framework \\
\hline 13 & $\begin{array}{ll}\text { 1. } & \text { Interconnected } \\
\text { institutional } \\
\text { arrangements } \\
\text { 2. Resource flows } \\
\text { 3. Governance structures }\end{array}$ & $\begin{array}{l}\text { Muegge } \\
(2011 b)\end{array}$ & $\begin{array}{l}\text { Complex adaptive } \\
\text { system }\end{array}$ \\
\hline
\end{tabular}




\begin{tabular}{|c|c|c|c|}
\hline & $\begin{array}{l}\text { 4. } \begin{array}{l}\text { Elements of the } \\
\text { subsystems } \\
\text { 5. Feedback loops }\end{array}\end{array}$ & & \\
\hline 14 & $\begin{array}{l}\text { 1. Desired outcomes } \\
\text { 2. Stakeholder groups } \\
\text { 3. Platform } \\
\text { 4. Governance } \\
\text { 5. Components }\end{array}$ & $\begin{array}{l}\text { Bailetti \& Bot } \\
\text { (2013) }\end{array}$ & $\begin{array}{l}\text { Multi-sided platform } \\
\text { as enabler of } \\
\text { regional economic } \\
\text { outcomes }\end{array}$ \\
\hline 15 & $\begin{array}{l}\text { 1. Number of sides to bring } \\
\text { on board } \\
\text { 2. Platform design } \\
\text { 3. Pricing structures } \\
\text { 4. Governance rules }\end{array}$ & Hagiu (2014) & $\begin{array}{l}\text { Multi-sided platform } \\
\text { as interaction } \\
\text { enabler }\end{array}$ \\
\hline 16 & $\begin{array}{l}\text { 1. Number of sides to bring } \\
\text { on board } \\
\text { 2. Investments made to } \\
\text { interact with each other } \\
\text { and benefits expected } \\
\text { from the interactions } \\
\text { 3. Control over the } \\
\text { contractual terms of the } \\
\text { direct interactions } \\
\text { between stakeholder } \\
\text { groups } \\
\text { 4. Platform design }\end{array}$ & $\begin{array}{l}\text { Hagiu \& Wright } \\
\text { (2015a) }\end{array}$ & $\begin{array}{l}\text { Multi-sided platform } \\
\text { as a business model }\end{array}$ \\
\hline 17 & $\begin{array}{l}\text { 1. Number of sides to bring } \\
\text { on board } \\
\text { 2. Investments made to } \\
\text { interact with each other } \\
\text { and benefits expected } \\
\text { from the interactions } \\
\text { 3. Control over the } \\
\text { contractual terms of the } \\
\text { direct interactions } \\
\text { between stakeholder } \\
\text { groups } \\
\text { 4. Platform design }\end{array}$ & $\begin{array}{l}\text { Hagiu \& Wright } \\
(2015 \mathrm{~b})\end{array}$ & $\begin{array}{l}\text { Multi-sided platform } \\
\text { to examine make vs } \\
\text { enable agents } \\
\text { decisions }\end{array}$ \\
\hline
\end{tabular}




\begin{tabular}{|c|c|c|c|}
\hline 18 & $\begin{array}{ll}\text { 1. } & \text { Context } \\
\text { 2. } & \text { Cooperation } \\
\text { 3. } & \text { Construct } \\
\text { 4. } & \text { Configuration } \\
\text { 5. } & \text { Capability } \\
\text { 6. } & \text { Change }\end{array}$ & $\begin{array}{l}\text { Rong et al. } \\
\text { (2015) }\end{array}$ & $\begin{array}{l}\text { Complex adaptive } \\
\text { system }\end{array}$ \\
\hline 19 & $\begin{array}{ll}\text { 1. } & \text { Set of stakeholders } \\
\text { 2. } & \text { Platform } \\
\text { 3. } & \text { Membership boundary } \\
\text { 4. } & \text { Participating } \\
& \text { organizations and } \\
\text { individuals }\end{array}$ & $\begin{array}{l}\text { Muegge \& } \\
\text { Mezen } \\
\text { (forthcoming) }\end{array}$ & $\begin{array}{l}\text { Multi-sided platform } \\
\text { as enabler of } \\
\text { regional economic } \\
\text { outcomes }\end{array}$ \\
\hline
\end{tabular}

Table 1 suggests that five perspectives were used to derive the sets of salient features of a business ecosystem: i) multi-sided platform, ii) architecture of participation, iii) biological ecosystem, iv) complex adaptive system, and v) semantic framework. Each perspective covers some aspects of business ecosystems that are unaddressed or under-addressed by the other perspectives.

Table 2 organizes each of the studies shown in Table 1 into one of the five perspectives and provides a count of the number of studies that fall into each perspective. 
Table 2: Studies that describe the defining features of a business ecosystem by perspective used to derive them

\begin{tabular}{|c|c|c|}
\hline & Dominant perspective & $\begin{array}{l}\text { Studies that described the defining } \\
\text { features of business ecosystems }\end{array}$ \\
\hline 1 & Multi-sided platform & $\begin{array}{ll}1 & \text { Iyer \& Davenport (2008) } \\
2 & \text { Boudreau \& Hagiu (2009) } \\
3 & \text { Bailetti (2010b) } \\
4 & \text { Boudreau (2010) } \\
5 & \text { Bailetti \& Bot (2013) } \\
6 & \text { Hagiu (2014) } \\
7 & \text { Hagiu \& Wright (2015a) } \\
8 & \text { Hagiu \& Wright (2015b) } \\
9 & \text { Muegge \& Mezen (forthcoming) }\end{array}$ \\
\hline 2 & Architecture of participation & $\begin{array}{ll}1 & \text { Baldwin \& Clark (2000 } \\
2 & \text { Baldwin \& Clark (2006) } \\
3 & \text { Adner (2006) } \\
4 & \text { West \& O'Mahony (2008) } \\
5 & \text { Adner and Kapoor (2010) }\end{array}$ \\
\hline 3 & Biological ecosystem & $\begin{array}{ll}1 & \text { Iansiti \& Levien (2004) } \\
2 & \text { Moore (2006) }\end{array}$ \\
\hline 4 & Complex adaptive system & $\begin{array}{ll}1 & \text { Muegge (2011b) } \\
2 & \text { Rong et al. }(2015)\end{array}$ \\
\hline 5 & Semantic framework & 1 Muegge (2011a) \\
\hline
\end{tabular}

Three of the 19 studies in Tables 1 and 2 used the multi-sided platform perspective to examine a venture creation ecosystem that delivers regional economic development outcomes (Bailetti, 2010b; Bailetti \& Bot, 2013; Muegge \& 
Mezen, forthcoming). None of the other perspectives have been used to examine a business ecosystem designed to deliver regional economic benefits.

\subsubsection{Multi-sided platform perspective}

A multi-sided platform enables direct interaction between two or more distinct stakeholder groups and each stakeholder group is affiliated with the platform. What is meant by affiliation is that stakeholders in each stakeholder group consciously make platform-specific resource contributions that are necessary to interact with other stakeholder groups (Hagiu \& Wright, 2015a).

Of the 19 studies shown in Table 1, nine used the multi-sided platform perspective to identify 14 defining features of a business ecosystem. These 14 features were reduced to six features as shown in Table 3.

The 14 features were reduced to six for two reasons. First, some of these "different" features were the result of using two names to refer to the same abstraction. For example, Iyer and Davenport (2008) referred to Google's platform as the keystone while all other eight studies used the word platform. Second, the level across abstractions was not the same. For example, Bailetti (2010b), Bailetti and Bot (2013) and Hagiu (2014) identify governance, a high-level abstraction, as a business ecosystem feature. However, the governance related features of other studies were at a lower level of abstractions. 
Table 3: Distinct features of a business ecosystem from a multi-sided platform perspective

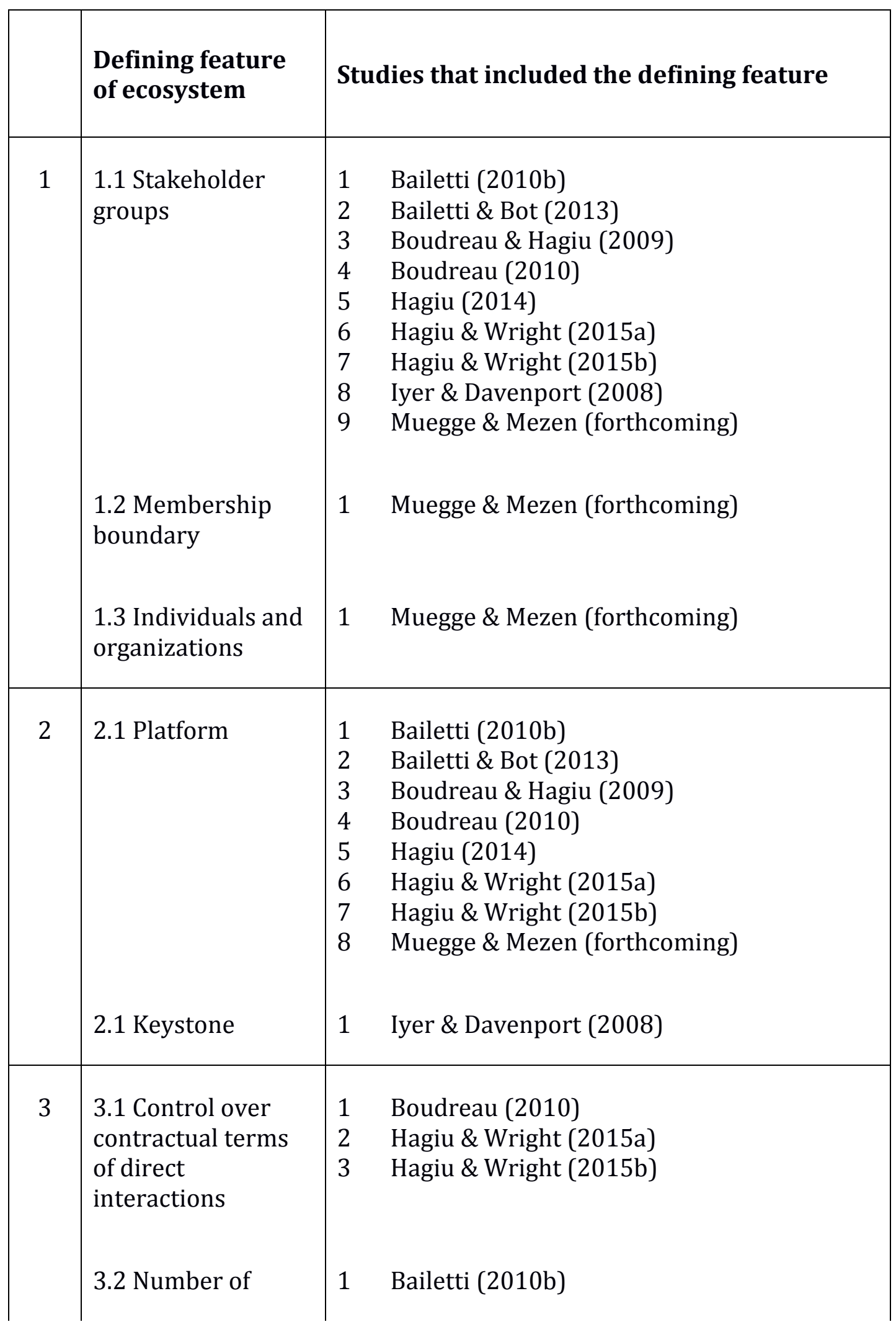




\begin{tabular}{|l|l|ll|} 
& $\begin{array}{l}\text { members per } \\
\text { stakeholder group }\end{array}$ & & \\
3.3 Open platform & 1 & Boudreau (2010) \\
aspects & 3.4 Governance & 1 & Bailetti (2010b) \\
& & $\begin{array}{l}\text { Bailetti \& Bot (2013) } \\
\text { Hagiu (2014) }\end{array}$ \\
\hline 4 & $\begin{array}{l}4.1 \text { Investment and } \\
\text { expected benefits }\end{array}$ & 1 & $\begin{array}{l}\text { Hagiu \& Wright (2015a) } \\
\text { Hagiu \& Wright (2015b) } \\
\text { Iyer \& Davenport (2008) }\end{array}$ \\
& $\begin{array}{l}\text { 4.2 Price structure } \\
1\end{array}$ & $\begin{array}{l}\text { Bailetti (2010b) } \\
\text { Boudreau \& Hagiu (2009) } \\
\text { Hagiu (2014) }\end{array}$ \\
\hline 5 & Desired outcomes & 1 & $\begin{array}{l}\text { Bailetti (2010b) } \\
\text { Bailetti \& Bot (2013) }\end{array}$ \\
\hline 6 & Health metrics & 1 & Bailetti (2010b) \\
\hline
\end{tabular}

The review of the multi-sided platform literature stream suggests that there are six defining features of a business ecosystem: i) stakeholder groups (includes membership boundary, and individuals and organizations), ii) platform (includes keystone), iii) control over contractual terms of direct interactions (includes number of members per stakeholder group, open platform aspects, and governance), iv) Investment and expected benefits (includes price structure), v) desired outcomes, and vi) health metrics. 


\subsubsection{Architecture of participation perspective}

Five of the 19 studies in Table 1 used the architecture of participation perspective to identify 12 defining features of a business ecosystem. These 12 features can be reduced to five features as shown in Table 4 .

Table 4: Distinct features of a business ecosystem from an architecture of participation perspective

\begin{tabular}{|c|c|c|}
\hline & Defining feature of ecosystem & $\begin{array}{l}\text { Studies that included the } \\
\text { distinct feature }\end{array}$ \\
\hline 1 & $\begin{array}{l}\text { Stakeholder groups } \\
1.1 \text { Complementors the focal firm } \\
\text { requires to move innovation forward } \\
1.2 \text { Intermediaries that adopt firm's } \\
\text { innovation } \\
1.3 \text { Suppliers and customers }\end{array}$ & $\begin{array}{ll}1 & \text { Adner (2000) } \\
2 & \text { Adner \& Kapoor (2010) } \\
1 & \text { Adner (2006) } \\
1 & \text { Adner \& Kapoor (2010) }\end{array}$ \\
\hline 2 & $\begin{array}{l}\text { 2.1 Focal firm } \\
\text { 2.2 Economic organization }\end{array}$ & $\begin{array}{ll}1 & \text { Adner \& Kapoor (2010) } \\
2 & \text { Baldwin \& Clark (2000) } \\
1 & \text { Baldwin \& Clark (2000) }\end{array}$ \\
\hline 3 & $\begin{array}{l}\text { Platform } \\
\text { 3.1 Components and complements } \\
\text { 3.2 Modularity in design }\end{array}$ & $\begin{array}{ll}1 & \text { Adner \& Kapoor (2010) } \\
1 & \text { Baldwin \& Clark (2000) } \\
2 & \text { Baldwin \& Clark (2006) }\end{array}$ \\
\hline
\end{tabular}




\begin{tabular}{|l|l|ll|} 
& $\begin{array}{l}3.3 \text { Option value } \\
3.4 \text { Intellectual property }\end{array}$ & 1 & Baldwin \& Clark (2006) \\
3.5 Organization of production & 1 & West \& O'Mahony (2008) \\
\hline 4 & $\begin{array}{l}\text { Risks due to interdependence with } \\
\text { complementors and adoption process }\end{array}$ & 1 & Adner (2006) \\
\hline 5 & Governance & 1 & West \& O'Mahony (2008) \\
\hline
\end{tabular}

The review of the architecture of participation literature stream suggests that there are five defining features of business ecosystems: i) stakeholder groups (including complementors the focal firm requires to move innovation forward, intermediaries that adopt firm's innovation, suppliers and customers, ii) focal firm (including economic organization), iii) platform (including components and complements; modularity in design, option value, intellectual property, and organization of production), iv) risks due to interdependence with complements and adoption process, and v) governance.

Platform modularity and option value are key aspects in platform architecture that affect members' participation. In design, a system is modular if its parts can be developed independently, but they are compatible and can work together to support the whole system. Option value means that participants (members) have the right to choose a course of actions, and do things in new ways as long as it provides an associated payoff. According to Baldwin and Clark (2006), 
the more modularity and value option, the more voluntary contributions and efforts will be, and the larger and more active the members are likely to be. These concepts, modularity and option value, are more understood in open source communities. However, they apply to any non-rival goods system or partially-rival goods system whose rivalry is below certain threshold. Therefore, it is important for platform leaders to control potential rivalry to maintain a mutually beneficial, voluntary collective effort.

After studying 12 sponsored open source projects, West and 0'Mahony (2008) introduced the basis for a participation architecture in communities. This architecture includes three dimensions for community design: the organization of production; community governance; and intellectual property. Decisions on the organization of production is related to how the production will take place, and one of its main aspects is modularity. Community governance is associated with who can join, and who can do or access what. Intellectual property is associated with the ownership and licensing of the community products. Community designers should make decisions about the openness of the community in all these three dimensions. Mostly these decisions are tradeoffs between openness and control. There are two distinct types of openness: transparency; and accessibility. Transparency allows outsiders to understand what is happening inside the community and why. Accessibility allows outsiders to influence the direction of the community in a way that serves their own goals. West and O'Mahony (2008) argue that the more openness a community has, the more it grows and attracts participants. 


\subsubsection{Biological ecosystem perspective}

Two of the 19 studies (Iansiti \& Levien, 2004; Moore, 2006) in Table 1 identified a total of 13 defining features of a business ecosystem. The five features identified by Iansiti and Levien (2004) were also identified by authors who contributed to the literature using the multi-sided platform and architecture of participation perspectives. The feature "organizations that use the platform" identified by Iansiti and Levien (2004) corresponds to the feature "stakeholder groups" shown in Table 3 and feature 1 in Table 4 which includes: Complementors the focal firm requires to move innovation forward; Intermediaries that adopt firm's innovation; and Suppliers and customers. Iansiti and Levin's "platform" corresponds to feature 2 in Table 3 and feature 3 in Table 4 . The feature "value derived and contributed by each stakeholder" corresponds to feature 4 in Table 3. "Keystone" is similar to feature 2 in Table 3 and feature 2 in Table 4.

The feature "ecosystem health" is better characterized by the ecological perspective of business ecosystem than by the other perspectives. While Bailetti (2010b) recognized "health metrics" as a feature, this concept is not well developed in the multi-sided platform perspective of business ecosystems.

The eight defining features of a business ecosystem identified by Moore (2006) are specified at a very high level of abstraction, which makes them hard to operationalize. The feature "campaigns for advancement", however, is distinct. The "campaigns for advancement" feature refers to the initiatives carried out to transform an ecosystem idea into reality creating benefits for society. 


\subsubsection{Complex adaptive system perspective}

Two of the 19 studies included in Table 1 (Muegge, 2011b; Rong et al., 2015) derive defining features of business ecosystems using two different complex adaptive system perspectives. There is little or no overlap between the two feature sets identified in these two studies.

Muegge's systems of systems perspective brings together technology platforms, companies' participation in business ecosystems, and individuals' participation in communities as a multi-level system (Muegge, 2011b). It links these subsystems through resource flows, interconnected institutional arrangements, and shared governance. In this multi-level system, the community is the locus of value creation, and the business ecosystem is the locus of commercialization and value capture. The platform sits in between as a shared commons resource, and it acts as a hub for both value creation and value capture. Participation in maintaining and extending a platform is a collective action. Muegge (2011b) argues that participation is driven by high modularity and open value at the platform level, transparency and accessibility at the community level, institutional features that structure participation and contribution at the ecosystem level, and institutional features that structure interactions between the three levels and motivate resource flows between them.

The 6C framework advanced by Rong et al. (2015) is a recent framework that its proponents have used to analyze business ecosystem. The $6 \mathrm{C}$ framework has six components: i) context, ii) cooperation, iii) construct, iv) configuration, v) capability, 
and vi) change. The context component identifies the environmental features of an ecosystem such as the driving forces, main barriers, and key missions. It mainly answers the question why certain ecosystem emerges. The cooperation component reflects the mechanisms by which ecosystem stakeholders interact to achieve system-level results. It mainly identifies the access and interaction regulations in the business ecosystem. The construct component defines the fundamental structure and supportive infrastructure of a business ecosystem. It mainly answers the question what the constructive elements of the business ecosystem are. Different business ecosystem frameworks can be used to identify the constructive elements of a business ecosystem. The configuration component represents the way elements in the construct are combined together. It mainly answers the question what anchors the ecosystem. The capability component identifies the key success features of a business ecosystem. It mainly answers the question why certain business ecosystem is better than another. The change component mainly answers the question how the ecosystem co-evolves.

\subsubsection{Semantic framework perspective}

Muegge (2011a) advanced the semantic framework perspective to better understand similarities and differences across business ecosystems. Muegge (2011a) first observes that authors employ the concept of business ecosystem in different ways and then develops a semantic framework comprised of four features: i) conceptual location, ii) anchor point, iii) membership boundaries, and iv) elemental building blocks. A conceptual location could be a system level of analysis 
above the firm, or an alternative mode of economic production. An anchor point could be a shared platform, focal firm, or no anchor point. Membership boundaries could be represented by the proximity to the ecosystem anchor, could be a property of the ecosystem member, or could be geographic boundaries like a regional cluster. Building blocks could be individuals and organizations, technologies, software services, etc.

\subsection{Launching new business ecosystems}

Launching a venture-creation ecosystem from the ground up is a complex process (Isenberg, 2010). Builders of new business ecosystems face at least four challenges: i) pragmatic reuse of components of existing ecosystems, ii) methods to bring on-board the stakeholder groups required to operate the new ecosystem, iii) bridging existing business ecosystems that may be at different stages of the business life cycle with new business ecosystem, and iv) understanding what makes a venture-creation business ecosystem different from other business ecosystems.

\subsubsection{Pragmatic reuse of business ecosystem components}

Depending on the quality desired, pragmatic reuse of business ecosystem components may be very effort-intensive. Consider a mentorship component of an ecosystem that operates successfully in a large city in the United States. Reusing the mentorship component in a region where mentorship is not a common practice may entail a significant amount of adaptation and integration effort. 
The pragmatic reuse of components of an existing business ecosystem refers to their reuse in a region for which they were not originally intended. At the time of this writing, the business ecosystem literature has not addressed the issue of pragmatic reuse of components of existing ecosystems. A review of the literature found no guidelines or criteria that can be used to select or adapt the components of existing ecosystems into new ecosystems.

Therefore, the researcher reviewed the literature on pragmatic reuse of software components to seek a better understanding of what component reuse entails. The rationale for connecting the notions of ecosystem component reuse and software component reuse is that venture-creation ecosystems and software systems are both artifacts produced by a design process (Simon, 1969; Baldwin \& Clark, 2000; Muegge, 2013). Component reuse is an architectural decision, and the notion of architecture underpins both multisided platforms that mediate economic transactions and engineering platforms of modular components (Gawer, 2014).

Pragmatic reuse of software components entails three activities - selection, adaptation and integration - and the software literature has focused more on adaptation than selection (Kessel \& Atkinson, 2015). Software developers need to select components that match an envisioned usage scenario. There is large variety of criteria influence the degree to which a component matches the reuse context of a developer, however, there is no single metric or set of metrics that best capture a component's "degree of match" in all usage scenarios in all software domains. Kessel and Atkinson (2015) propose two concepts tailored to the pragmatic reuse of 
software components to support the selection decision of what components to reuse, each concept provide a unique viewpoint on the component. These two concepts are: functional sufficiency, and superfluous functionality. The functional sufficiency concept measures the extent to which a component delivers the desired functionality for a certain usage scenario. Based on this metric, a component could be unsuitable, functionally sufficient, or partially functional sufficient. Even though a component could be partially or fully functional sufficient (fulfills the requirements of a particular usage scenario), it may also include functionalities that are not needed by the usage scenario. These not needed or irrelevant functionalities are called superfluous functionalities, and they may impact the maintainability and verifiability of the component in the new application. Components that are partially functional sufficient and components with superfluous functionalities may require invasive changes to their code base to adapt them for the new usage scenario. Developers should rank components based on the relative effort needed to adapt them for the new usage scenario and select the ones with the minimum needed effort for the pragmatic reuse.

\subsubsection{Methods to bring on-board requisite stakeholder groups}

Bringing on-board stakeholder groups to contribute to a business ecosystem is difficult; particularly for business ecosystems designed using the multi-sided platform perspective. A stakeholder group derives value from the multi-sided platform only if there are other stakeholder groups on the platform. Therefore, multi-sided platform builders should figure out ways to onboard the stakeholder 
groups on the platform. Evans (2009) and Edelman (2015) identify various ignition tactics to onboard stakeholder groups. These tactics include:

- Sequential entry: onboard one side first, then onboard the others. This tactic works best in the case of non-positive indirect network effect.

- Basic zig-zag: build participation on each side incrementally. Start with small number of stakeholders on each side, then move to other sides to convince them to join.

- Attract large number of stakeholders at once: target either physical or online aggregators where you can find large number of intended stakeholders in one place.

- Stand-alone value: add a service or a feature that makes the platform valuable for a stakeholder even if nobody else joins.

- Start with industry niche: find a niche that is valuable to your stakeholders.

- Build small social groups: build groups around shared goals or interests.

- Target marquee stakeholders: these stakeholders are usually known to other stakeholders, and when they join they provide high credibility to the platform.

- Reduce joining risks: reduce commitments, especially financial commitment.

- Ensure compatibility: offer just enough compatibility with legacy systems to attract stakeholders. Anticipate resistance. 


\subsubsection{Stage of business ecosystem lifecycle}

Moore $(1993,1996)$ advanced the concept of business ecosystem life cycle to complement the concepts of product, technology and industry life cycles. He argued that the business ecosystem life cycle perspective represents the comprehensive situation of an across-industries collaboration. According to Moore (1993), a business ecosystem life cycle has four sequential stages: birth, expansion, leadership, and self-renewal. In the "birth" stage, firms watch for new opportunities to setup value chains and create value for customers. In the "expansion" stage, firms would be able to deliver their offerings to a larger number of customers by working with suppliers and partners. In the "leadership" stage, value adding processes are stable, and business ecosystem leaders set a vision to encourage collaboration. In the last stage, firms work with innovators to bring new ideas to the existing ecosystem.

\subsubsection{Building venture-creation business ecosystems}

Lead To Win is a venture-creation ecosystem that was deliberately designed by professors from Carleton University to be a job-creation engine for Canada's capital region (Bailetti \& Hudson, 2009).

A venture-creation ecosystem is an environment that supports and nurtures entrepreneurship in a certain area to achieve regional economic development outcomes (i.e., jobs created, investment attracted, sales generated, etc.). Some venture-creation ecosystems evolve naturally due to advanced industries, strong 
academic institutions, military industries, venture capital, or the interaction between all these sectors (Isenberg, 2010). Good examples of these ecosystems include the Silicon Valley, and Boston ecosystems.

To jump-start the creation and growth of a venture-creation ecosystem, Isenberg (2010) suggests nine actions: i) stop emulating Silicon Valley, ii) shape the ecosystem around local conditions, iii) engage the private sector from the start, iv) favor the high potentials, v) get a big win to the board, vi) tackle cultural change head-on, vii) stress the roots by providing money carefully, to ensure that entrepreneurs develop toughness and resourcefulness, viii) don't over-engineer clusters, help them grow organically, and ix) reform legal, bureaucratic, and regulatory frameworks.

To develop a business ecosystem Isenberg (2010) recommends to "experiment relentlessly, yet holistically". He says "you can never have enough entrepreneurship, there are no right answers, and there is no choice but for policy makers and leaders to continue to experiment and learn how to enhance their ecosystems". 


\subsection{Lead To Win}

This section examines the literature on Lead To Win.

\subsubsection{About Lead To Win}

Lead To Win is a venture-creation ecosystem that delivers services to entrepreneurs for the purpose of contributing to the economic development of Canada's Capital Region (Bailetti \& Bot, 2013). Initially, each venture in the ecosystem was expected to create a minimum of six knowledge jobs in Canada's Capital Region within three years. This objective was changed subsequently. Currently the expectation is that each venture should generate annual revenue of one million dollars within three years (Mezen, 2014).

The success of Lead To Win is measured in terms of the number of jobs created, new company revenue, and amount of direct investment attracted to Canada's Capital Region rather than the number of seats-filled in seminars or sessions-delivered (Bailetti \& Hudson, 2009). System-level results such as job creation, sales generation, and investment attracted play an essential role in branding Lead To Win and attracting participation.

At the time of this writing, the material used to describe the Lead To Win ecosystem to entrepreneurs includes the following information (Bailetti, 2015a):

"Lead To Win:

- Provides many free services while making progress towards generating \$1 
M/year revenue for a business that YOU own - takes no equity position or makes claims on intellectual property

- Enables rapid globalization early

- Reduces time-to-cash

- Helps develop "something" for which customers are willing to pay, help improve, and refer to others

- Supports stakeholders' network anchored on venture

- Applies research and practical experience to improve likelihood of venture's success

- Enhances capacity to sell to first customers, raise funds, and attract and retain talent"

\subsubsection{Academic literature on Lead To Win}

Bailetti and Hudson (2009), Bailetti (2010a), Bailetti and Bot (2013), Mezen (2014), and Muegge and Mezen (forthcoming) have contributed to the literature on Lead To Win. The early experience gained operating Lead To Win and the fledging literature on multi-sided platforms, particularly Boudreau and Hagiu (2009) and Evans, Hagiu and Schmalensee (2008), influenced the drive to incorporate advances in business ecosystem into Lead To Win (Bailetti, 2010b, 2010c; Bailetti \& Prattico, 2009; Makienko \& Misaka, 2011).

Muegge and Mezen (forthcoming) used five perspectives to examine Lead To Win (as it existed in 2014) and to produce two representations: i) Lead To Win as a multi-sided platform, and ii) Lead To Win as a multi-level system. 
Muegge and Mezen (forthcoming) applied the multi-sided perspective to specify Lead To Win as ten stakeholder groups interacting through a process for venture creation. Table 5 identifies the stakeholder groups that Muegge and Mezen (forthcoming) reported as being part of Lead To Win. For each stakeholder group, Table 5 identifies the participants at each side, and the value propositions to participants.

Table 5: Stakeholder groups, participants and value propositions of Lead To Win

\begin{tabular}{|l|l|l|}
\hline $\begin{array}{l}\text { Side of the } \\
\text { multisided } \\
\text { platform }\end{array}$ & $\begin{array}{l}\text { Participants comprising the } \\
\text { platform side }\end{array}$ & $\begin{array}{l}\text { Value propositions for } \\
\text { participants }\end{array}$ \\
\hline 1. Entrepreneurs & $\begin{array}{l}\text { Entrepreneurs lead the creation } \\
\text { of ventures to become leaders of } \\
\text { the startup community }\end{array}$ & $\begin{array}{l}\text { Wealth creation; bringing } \\
\text { about technological or } \\
\text { social change; } \\
\text { emancipation from } \\
\text { working for others. }\end{array}$ \\
\hline 2. Implementers & $\begin{array}{l}\text { Implementers bring about and } \\
\text { build the ventures' offers; may } \\
\text { include employees, directors, } \\
\text { advisors, and contactors who } \\
\text { have a direct financial stake in } \\
\text { the venture }\end{array}$ & $\begin{array}{l}\text { Direct financial returns } \\
\text { through payments or } \\
\text { equity; wide range of } \\
\text { personal and professional } \\
\text { motivations. }\end{array}$ \\
\hline 3. Mentors & $\begin{array}{l}\text { Mentors provide domain } \\
\text { knowledge or managerial } \\
\text { expertise; mentors are } \\
\text { volunteers with no financial } \\
\text { stakes in the ventures they } \\
\text { assist }\end{array}$ & $\begin{array}{l}\text { Building and maintaining } \\
\text { networks with other } \\
\text { mentors; exchanging } \\
\text { information; building } \\
\text { good-will. }\end{array}$ \\
\hline
\end{tabular}




\begin{tabular}{|c|c|c|}
\hline & & $\begin{array}{l}\text { satisfaction and a sense of } \\
\text { either "giving back" or } \\
\text { "paying forward" }\end{array}$ \\
\hline $\begin{array}{l}\text { 4. Post-secondary } \\
\text { institutions }\end{array}$ & $\begin{array}{l}\text { Universities and colleges } \\
\text { provide entrepreneurial } \\
\text { knowledge and assets, } \\
\text { reviewers for opportunity } \\
\text { assessments, entrepreneurs, } \\
\text { implementers, lab access and } \\
\text { research ready to commercialize }\end{array}$ & $\begin{array}{l}\text { Consistent with the } \\
\text { mission of schools: } \\
\text { enhance brand and } \\
\text { reputation in the } \\
\text { community, attract } \\
\text { graduate students, } \\
\text { provide opportunities to } \\
\text { students and faculty. }\end{array}$ \\
\hline 5. Service providers & $\begin{array}{l}\text { Professionals provide services } \\
\text { to ventures; may include } \\
\text { accountants, lawyers, and } \\
\text { human resources providers }\end{array}$ & $\begin{array}{l}\text { Build brand and } \\
\text { reputation; build } \\
\text { connections with future } \\
\text { customers; various } \\
\text { intrinsic motivations. }\end{array}$ \\
\hline 6. Business partners & $\begin{array}{l}\text { Commercial entities may } \\
\text { establish operational } \\
\text { partnerships with ventures; may } \\
\text { include channel to market } \\
\text { partners, supply chain partners, } \\
\text { and manufacturing partners }\end{array}$ & $\begin{array}{l}\text { Access to 'green' ventures } \\
\text { that may be less risk than } \\
\text { other early-stage } \\
\text { ventures; build } \\
\text { connections for future } \\
\text { opportunities; potential } \\
\text { for strategic and financial } \\
\text { returns. }\end{array}$ \\
\hline 7. Complementors & $\begin{array}{l}\text { Providers of products and } \\
\text { services that complement the } \\
\text { products or services of ventures; } \\
\text { complements make ventures' } \\
\text { products and services more } \\
\text { valuable to customers }\end{array}$ & $\begin{array}{l}\text { Potential for strategic and } \\
\text { financial returns. }\end{array}$ \\
\hline $\begin{array}{l}\text { 8. Economic } \\
\text { development } \\
\text { organizations }\end{array}$ & $\begin{array}{l}\text { Public and not-for-profit groups } \\
\text { provide grants and other } \\
\text { assistance to ventures, } \\
\text { communities, and the } \\
\text { organizations that support them }\end{array}$ & $\begin{array}{l}\text { Support of policy } \\
\text { objectives to foster } \\
\text { economic growth, job } \\
\text { creation, and } \\
\text { entrepreneurship. }\end{array}$ \\
\hline
\end{tabular}




\begin{tabular}{|l|l|l|}
\hline $\begin{array}{l}\text { 9. Early buyers and } \\
\text { users }\end{array}$ & $\begin{array}{l}\text { "Early adopters" (Rogers, 2003; } \\
\text { Moore, 1999) are willing - even } \\
\text { eager - to try and buy new } \\
\text { products or services at the } \\
\text { earliest stages of discontinuous } \\
\text { change, providing early } \\
\text { feedback and building } \\
\text { legitimacy for the venture }\end{array}$ & $\begin{array}{l}\text { Earliest access to new } \\
\text { products and services; } \\
\text { opportunities to influence } \\
\text { product development; } \\
\text { opportunities to innovate. }\end{array}$ \\
\hline 10. Investors & $\begin{array}{l}\text { Angel investors, angel groups, } \\
\text { strategic investors, and venture } \\
\text { capital investors provide capital } \\
\text { to grow ventures }\end{array}$ & $\begin{array}{l}\text { Access to 'green' ventures; } \\
\text { potential for high returns } \\
\text { on early-stage investment. }\end{array}$ \\
\hline
\end{tabular}

Source: Muegge and Mezen (forthcoming, Table 4)

Using the semantic framework perspective, Muegge and Mezen (forthcoming) described Lead To Win as a set of stakeholders, anchored around a process platform, bounded by accepting an invitation to participate, where the participants are both organizations and individuals.

Muegge and Mezen (forthcoming) uses the description of Bailetti and Bot (2013) to describe the Lead To Win platform as a process where: "Technology entrepreneurs whose opportunities have been rated 'green' by the Lead To Win Opportunity Review Board receive benefits (e.g., services) from program elements that are organized into five components. These components differ in terms of the value they add to creating jobs and the specialized knowledge required for delivering these services." Muegge and Mezen (forthcoming, Table 6) identify the components of Lead To Win platform and organize them into categories using the five-component framework from Bailetti and Bot (2013). 
Muegge and Mezen (forthcoming) argue that Lead To Win has high

modularity and option value in use and in design. It has high modularity and option value in use because entrepreneurs have the flexibility to choose, consume, and combine components of Lead To Win as desired, and because services can be accessed when and if they are most valuable to entrepreneurs. Also, it has high modularity and option value in design since Lead To Win organizers can add new elements and entrepreneurship programs or reconfigure the existing ones in response to stakeholders needs and interests.

Applying the system perspective to examine Lead To Win, at the level of people, Muegge and Mezen (forthcoming) identify the Lead To Win community as a voluntary group of people with common interests and a shared sense of identity that maintains and extends the Lead To Win platform. Production in Lead To Win happens through voluntary contributions of time, expertise, fund, and resources. The council of Lead To Win make decisions and orchestrates all the events and processes of Lead To Win. Some of Lead To Win outputs have open access and some of them allow access only for entrepreneurs with "green" rated opportunities.

\subsection{Entrepreneurship in Jordan}

In his article "How to Start an Entrepreneurial Revolution", Isenberg (2010) states that economic studies usually link entrepreneurship to rapid job-creation, Gross Domestic Product growth, and long-term productivity increases. Promotion of entrepreneurship has changed the faces of several countries like Rwanda, Taiwan, Colombia, and others. Other than improving the economic status of these countries, 
promotion of entrepreneurship decreased the brain drain, improved the social environment, and reduced crime. Entrepreneurship in the essence is proactivity. It enables individuals to create the world they like without waiting for someone or for the government to do all the changes. Therefore, entrepreneurship culture and knowledge is spreading everywhere. Even though some people doesn't realize all its dimensions, they know that they can do something, they can learn, and they can make a difference.

Youth in countries in the Middle East and North Africa (MENA) are becoming increasingly aware that entrepreneurship is the way to make a difference in their societies. According to a recent report about entrepreneurship in the MENA area from Wamda Research Lab (Wyne, 2014), 60\% of new entrepreneurial initiatives in the MENA are located in Jordan, Egypt, Lebanon and UAE. In Jordan, the acquisition of Maktoob, the Arab Internet Portal, by Yahoo in 2009, was a success story that triggered entrepreneurship initiatives in the country. One of the main initiatives that started right after this success story is Oasis500. With the full support of the king of Jordan, King Abdullah II, Oasis500 started with an ambitious goal to create 500 Maktoobs (500 exits) in 5 years. It provides several services to entrepreneurs like entrepreneurship training, mentorship, workspace, and early stage funding, which covers lots of business ecosystem aspects. Also, it walks entrepreneurs through a clear process of training and filtration to select opportunities that are eligible for funding. Eligible opportunities receive a seed fund against equity in the company. What distinguishes Oasis500 is their high quality network of business men, mentors and investors from all over the world. INJAZ is another initiative that 
opens youths' minds on business and entrepreneurship through several programs and competitions. They are well connected with high schools and key ministries in Jordan. In addition, lots of accelerators and incubators has been launched, some of them are just work spaces for entrepreneurs, and few of them have real acceleration programs. Some of these incubators/accelerators are iPark, Oasis500, Umniah Plug \& Play, and Al Urdonia Lil Ebda that has several incubators in different Jordanian cities. In terms of early stage capital and venture capital, there has been several initiatives like Oasis angel network, Silicon Badia, and DASH ventures.

According to Wamda Research Lab (Wyne, 2015) the top four challenges that face entrepreneurs in Jordan are: obtaining investment; generating revenue; expanding into new countries; and building a team. Even though there are several initiatives that try to provide early stage capital and venture capital to startups, experts and entrepreneurs agree that there is still lack in this kind of capital. However, experts also mention that another barrier for entrepreneurs to secure investments is their lack of understanding of what investors are looking for.

The challenge of generating revenue, according to the report, is due to three factors: problem in marketing products or services; problem in finding customers; and problem in collecting payments on goods or services sold. Expanding into new countries is a serious challenge for entrepreneurs because of the small market size in Jordan.

The main challenges for expansion are finding partners, cost, and legal process required for setting up a business. The challenge of building a team is 
associated with attracting, developing, and retaining talented individuals (Wyne, 2015).

\subsection{Lessons learned}

Researchers with at least five different perspectives have contributed defining features of business ecosystems to the academic literature. These perspectives include: multi-sided platform, architecture of participation, biological ecosystem, complex adaptive system, and semantic framework.

Six defining features for business ecosystems were identified in the multisided platform literature stream: i) stakeholder groups (includes membership boundary, and individuals and organizations), ii) platform (includes keystone), iii) control over contractual terms of direct interactions (includes number of members per stakeholder group, open platform aspects, and governance), iv) investment and expected benefits (includes price structure), v) desired outcomes, and vi) health metrics.

The literature on business ecosystems does not provide criteria or guidelines to select or adapt components of existing ecosystems into new ecosystems. The software literature may be useful to develop such guidelines.

The business ecosystem life cycle has four stages: birth, expansion, leadership, and self-renewal. 
Lead To Win is a venture-creation ecosystem designed to deliver economic development benefits in Canada's Capital Region. Each venture in Lead To Win is expected to generate annual revenue of $\$ 1$ million within three years from its inception.

Conceptualized as a multi-sided platform, Lead To Win has 10 sides, where each side invests cash or in-kind to Lead To Win and derives certain benefits.

Building a new venture creation ecosystem in a geographic area requires adaptation to the needs of the area and continuous experimentation.

The business ecosystem in Jordan is still young, and there is lots of room for improvement. While many initiatives support entrepreneurship in Jordan, a business ecosystem that delivers benefits similar to those delivered by Lead To Win in Canada’s Capital Region does not exist.

\subsection{Summary}

The literature on business ecosystems continues to grow. This research is varied, large, and fragmented.

This chapter reviewed the articles on business ecosystems published in the English language by North American and European based academic journals and a few unpublished studies for the purpose of: i) identifying the defining features of business ecosystems, ii) examining the launch of new ecosystems, iii) summarizing what is known about the Lead To Win ecosystem, and iv) identifying the challenges of entrepreneurship in Jordan. 
In addition, this chapter also includes a review of the recent literature on pragmatic reuse of software components for the purpose of identifying the criteria to use to select components of existing business ecosystems to reuse in new ecosystems.

The review of the literature found 19 studies that discussed the defining features of business ecosystems and that five perspectives were used to derive them. These perspectives are: i) multi-sided platform, ii) architecture of participation, iii) biological ecosystem, iv) complex adaptive system, and v) semantic framework.

Nine of the 19 studies used the multi-sided platform perspective to identify the defining features of business ecosystems. The review of the nine studies suggests that there are six defining features of a business ecosystem: i) stakeholder groups (includes membership boundary, and individuals and organizations), ii) platform (includes keystone), iii) control over contractual terms of direct interactions (includes number of members per stakeholder group, open platform aspects, and governance), iv) Investment and expected benefits (includes price structure), v) desired outcomes, and vi) health metrics.

Chapter 2 also provides a review of four topics that are related to building new business ecosystems: i) pragmatic reuse of components of existing ecosystems, ii) methods to bring on-board the stakeholder groups required to operate the new ecosystem, iii) bridging existing business ecosystems that may be at different stages of the business life cycle with new business ecosystem, and iv) understanding what 
makes a venture-creation business ecosystem different from other business ecosystems.

The literature on Lead To Win includes Bailetti and Hudson (2009), Bailetti (2010a), Bailetti and Bot (2013), Mezen (2014), and Muegge and Mezen (forthcoming). The early experience gained operating Lead To Win and the fledging literature on multi-sided platforms, particularly Boudreau Hagiu (2009) and Evans, Hagiu and Schmalensee (2008), influenced the drive to incorporate advances in business ecosystem into Lead To Win (Bailetti, 2010b, 2010c; Bailetti \& Prattico, 2009, Makienko \& Misaka, 2011).

The top four challenges that face entrepreneurs in Jordan are: obtaining investment; generating revenue; expanding into new countries; and building a team. 


\section{Research Method}

Chapter 3 describes the method that will be used to carry out this research. It is organized into three sections. Section 3.1 describes the approach of this research. Section 3.2 describes the method used to carry out this research. Section 3.3 provides a summary of this chapter.

\subsection{Approach}

This research is exploratory; it is initial research into the observation that the extant literature does not explain how the components of a regional business ecosystem can be reused to build a new ecosystem to deliver similar outcomes in another region. This research seeks to understand how to best fill this gap in the literature. The intent is to explore the research question; not to offer final and conclusive solutions to an existing problem (Brown, 2006; Singh, 2007).

This exploratory research lays the groundwork to future research into a new angle in the business ecosystem domain: pragmatic reuse of business ecosystem components. For this purpose, this research has been conducted as methodologically as possible.

\subsection{Research method}

Table 6 identifies the six steps used to carry out this research. For each step, the dominant activity and the step's outcome are identified. 
Table 6: Research method

\begin{tabular}{|c|c|c|}
\hline Step & Dominant activity & Outcome \\
\hline 1 & $\begin{array}{l}\text { Review literature to identify the } \\
\text { defining features of business } \\
\text { ecosystems and develop a } \\
\text { framework that can enable the } \\
\text { pragmatic reuse of business } \\
\text { ecosystem components }\end{array}$ & $\begin{array}{l}\text { - Set of defining features of business } \\
\text { ecosystems } \\
\text { - Framework to specify a business } \\
\text { ecosystem } \\
\text { - Criteria to select business ecosystem } \\
\text { components that can be reused } \\
\text { when building a new ecosystem }\end{array}$ \\
\hline 2 & $\begin{array}{l}\text { Specify the Lead To Win-Ottawa } \\
\text { ecosystem using the framework } \\
\text { developed }\end{array}$ & $\begin{array}{l}\text { Specification of the Lead To Win-Ottawa } \\
\text { ecosystem }\end{array}$ \\
\hline 3 & $\begin{array}{l}\text { Review the literature about } \\
\text { entrepreneurship in Jordan and } \\
\text { select the platform components } \\
\text { to include in the Lead to Win- } \\
\text { Jordan ecosystem }\end{array}$ & $\begin{array}{l}\text { The set of platform components to } \\
\text { include in Lead To Win-Jordan }\end{array}$ \\
\hline 4 & $\begin{array}{l}\text { Specify the Lead To Win-Jordan } \\
\text { business ecosystem }\end{array}$ & $\begin{array}{l}\text { Specification of the Lead To Win-Jordan } \\
\text { business ecosystem using the platform } \\
\text { developed }\end{array}$ \\
\hline 5 & $\begin{array}{l}\text { Develop a plan to implement } \\
\text { the new ecosystem Lead To } \\
\text { Win-Jordan }\end{array}$ & Implementation plan \\
\hline 6 & $\begin{array}{l}\text { Generalize the lessons learned } \\
\text { about the reuse of components } \\
\text { of the Lead To Win ecosystem } \\
\text { to build a new business } \\
\text { ecosystem }\end{array}$ & $\begin{array}{l}\text { Method to design and implement a } \\
\text { regional venture creation ecosystem } \\
\text { that reuses components of another } \\
\text { ecosystem }\end{array}$ \\
\hline
\end{tabular}


3.2.1 Step 1: Review the literature and develop framework to specify business ecosystems

The first step entailed three parts. The first part was to review the business ecosystem literature for the purpose of identifying the defining features of business ecosystems and criteria to select the components of a business ecosystem that can be reused to build a new ecosystem in a different region.

The second part was the development of a framework that can be used to specify existing and new business ecosystems.

The review of the business ecosystem literature did not identify criteria to select and augment the components that can be reused to build a new business ecosystem. Therefore, the researcher reviewed the recent literature on code reuse and used the lessons learned to develop the criteria to select business ecosystem components for reuse.

\subsubsection{Step 2: Specify the Lead To Win-Ottawa business ecosystem}

The second step consisted on using the framework developed in Step 1 to specify the Lead To Win-Ottawa ecosystem for the purpose of enabling the use of its components to build a new venture-creation business ecosystem.

The researcher first asked two individuals who are core to the operations of Lead To Win ecosystem a set of general and specific questions. The general questions asked included: i) what is the environment for startups in Ottawa?, ii) 
who are the people and organizations involved with venture creation in Ottawa and what motivates their involvement?, iii) how does Lead To Win work?

The specific questions asked are: i) what are the goals and objectives of Lead To Win?, ii) what are the components and elements of Lead To Win?, iii) how does each component work?, iv) what drives changes in Lead To Win?, v) who are the various stakeholders of Lead To Win?, vi) what does each stakeholder group contribute to Lead To Win?, vi) what does each stakeholder benefit from participating in Lead To Win?

The intent of the informal interviews was to identify the shareholder groups engaged in the ecosystem and for each shareholder group identify the contributions they made to the process platform and expected benefits.

The researcher then interviewed six participants in Lead To Win, three of them are professionals who review opportunities and asked them to provide the contributions they make to Lead To Win and their expected benefits.

The researcher then produced a synthesis of the information provided in Muegge and Mezen (forthcoming), the information provided by the two individuals who are core to the operations of Lead To Win, and the six participants of Lead To Win. 
The synthesis in tabular form was provided to three individuals engaged with the operations of Lead To Win-Ottawa with a request that they made requisite corrections. A revised version of this table was produced by the researcher. This revised version was once again showed to the same three individuals who contributed changes until a final table with the information was produced.

The components and elements of Lead to Win as of 2015 were obtained from Bailetti (2015b).

\subsubsection{Step 3: Review the literature about entrepreneurship in Jordan and} select the components to include in the Lead to Win-Jordan ecosystem

The researcher reviewed the literature about entrepreneurship in Jordan to better understand the current environment, key players, and challenges that entrepreneurs face in Jordan and produced a set of lessons learned about entrepreneurship in Jordan.

Using the criteria developed in step 1, the researcher selected the components of Lead To Win-Ottawa to be included in Lead To Win-Jordan.

\subsubsection{Step 4: Specify the four parts of the Lead To Win-Jordan ecosystem}

In step four, the researcher:

- Designed a semi-structured interview protocol to capture knowledge about potential stakeholders for LTW-Jordan and their value propositions and 
identify individuals that have knowledge about entrepreneurship in Jordan to be interviewed

- Conducted semi-structured interviews with individuals who have knowledge about entrepreneurship in Jordan

- Produced a list of potential stakeholders for LTW-Jordan as well as their value propositions and contributions

- Specified Lead To Win-Jordan using the framework identified in the first step

- Compared Lead To Win-Ottawa and Lead To Win-Jordan in terms of the components used

The researcher designed a protocol for semi-structured interviews and interviewed eight individuals who have knowledge about entrepreneurship in Jordan. The intent was for the protocol to capture knowledge about potential stakeholders for Lead To Win-Jordan who could provide contributions similar to the ones provided by Lead To Win-Ottawa stakeholders, and the value propositions of these potential stakeholders. The researcher was raised in Jordan and already has connections with individuals that have knowledge about entrepreneurship in Jordan. The researcher leveraged his connections to recruit the eight interviewees.

The researcher conducted semi-structured interviews following the protocol produced. During the interviews the researcher wrote down the responses of the interviewees.

The researcher analyzed the responses generated during the interviews and produced a list of potential stakeholders for Lead To Win Jordan. These 
stakeholders were expected to provide contributions similar to the ones provided by Lead To Win-Ottawa stakeholders.

The researcher then specified Lead To Win-Jordan using the four parts framework identified from Step 1.

Finally, the researcher compared Lead To Win-Ottawa and Lead To WinJordan for the purpose of identifying their similarities and differences.

\subsubsection{Step 5: Develop a plan to implement the new ecosystem Lead To Win- Jordan}

The researcher used the lessons learned about launching multi-sided platforms (Evans, 2009; Edelman, 2015), lessons learned about entrepreneurship in Jordan, and the specifications of Lead To Win-Jordan to propose a plan to implement the Lead To Win-Jordan ecosystem. Tactics on launching multi-sided platforms are used in the context of Jordan to attract participation in the early stages of building the Lead To Win-Jordan ecosystem.

\subsubsection{Step 6: Generalize the lessons learned about reusing components of Lead} To Win-Ottawa in a different region

The researcher generalized the lessons learned about how to reuse components of Lead To Win-Ottawa in other regions of the world. This step resulted with a general four-step method that the researcher believes can be used to design and implement a regional venture-creation ecosystem that reuses components of 
another ecosystem.

\subsection{Summary}

Chapter 3 describes the approach and the step by step method that was carried out to produce the following deliverables:

1. Framework to specify a business ecosystem

2. Specifications of the Lead To Win-Ottawa and Lead To Win-Jordan venturecreation ecosystems using the framework

3. Plan to implement the Lead To Win-Jordan venture-creation ecosystem

4. Method to design and implement a regional venture creation ecosystem that reuses components of another ecosystem 


\section{Results}

Chapter 4 provides the results of the research. The chapter is organized into seven sections. The framework to specify business ecosystems is included in Section 4.1. Section 4.2 provides the specification of the Lead To Win-Ottawa ecosystem. Section 4.3 provides the criteria to select components of the Lead To Win-Ottawa business ecosystem for reuse in the Lead To Win-Jordan ecosystem. Section 4.4 provides the specification of the Lead To Win-Jordan business ecosystem. An overview of the plan to implement the Lead To Win Jordan business ecosystem is provided in Section 4.5. Section 4.6 provides a generalized method for the pragmatic reuse of components of an existing business ecosystem to build a new business ecosystem. Finally, section 4.7 provides the summary.

\subsection{Framework to specify business ecosystems}

The researcher decided to specify business ecosystems using the multi-sided platform perspective and the following four defining features:

1. sides

2. platform

3. control over contractual terms of direct interactions

4. desired outcomes

Of the five perspectives on defining business ecosystems, the researcher decided that the multi-sided perspective had more to offer than the others at this time because of its theoretical base. While each of the other perspectives may be 
able to improve our understanding of business ecosystems, for the purpose of exploring the research question, this study would be better served by selecting one perspective over a potpourri of perspectives.

The review of the multi-sided platform literature stream suggests that there are six defining features of a business ecosystem: i) stakeholder groups (includes membership boundary, and individuals and organizations), ii) platform (includes keystone), iii) control over contractual terms of direct interactions (includes number of members per stakeholder group, open platform aspects, and governance), iv) Investment and expected benefits (includes price structure), v) desired outcomes, and vi) health metrics.

When a side of a multi-sided platform is defined as the stakeholder group comprised of participants that make similar investments and expect similar benefits when affiliated with a platform, investments and expected benefits become subfeatures of the side feature, and the number of defining features of a business ecosystem can be reduced from six to five. This is consistent with the new conceptualization of a multi-sided platform offered by Hagiu and Wright (2015a).

It is unclear to the researcher whether or not "desired outcomes" and "health metrics" are two independent defining features of business ecosystems. They may be different perspectives on the same abstraction. The Lead To Win experience suggests that defining "desired objectives" as system level outcomes binds together the stakeholders working to create regional economic benefits. These stakeholders were more concerned with "desired outcomes" than with "health metrics." 
Therefore, the researcher excluded "health metrics" as a defining feature of the business ecosystem. This led to the identification of the four defining features identified above.

Table 7 identifies the framework used to specify the existing Lead To WinOttawa and the new Lead To Win-Jordan business ecosystems. This framework is organized around the four salient features and their sub-features identified in the literature review.

Table 7: Framework to specify a business ecosystem using the multi-sided platform perspective

\begin{tabular}{|c|c|c|c|}
\hline & $\begin{array}{l}\text { Defining } \\
\text { feature }\end{array}$ & Sub-features & Details \\
\hline 1 & Side & $\begin{array}{l}\text { 1. Contributions to platform } \\
\text { (e.g., cash, assets, in-kind } \\
\text { time and effort) } \\
\text { 2. Benefits expected to be } \\
\text { derived from the } \\
\text { platform }\end{array}$ & $\begin{array}{l}\text { - Individuals and } \\
\text { organizations that } \\
\text { participate } \\
\text { - Membership boundary }\end{array}$ \\
\hline 2 & Platform & $\begin{array}{l}\text { 1. Processes } \\
\text { 2. Components } \\
\text { 3. Elements }\end{array}$ & \\
\hline 3 & $\begin{array}{l}\text { Control over } \\
\text { contractual } \\
\text { terms of direct } \\
\text { interactions }\end{array}$ & $\begin{array}{l}\text { 1. Control over sides' } \\
\text { interactions } \\
\text { 2. Open platform aspects } \\
\text { 3. Governance }\end{array}$ & $\begin{array}{l}\text { - Number of members per } \\
\text { stakeholder group }\end{array}$ \\
\hline 4 & $\begin{array}{l}\text { Desired } \\
\text { objectives }\end{array}$ & $\begin{array}{l}\text { System level objectives that } \\
\text { bind stakeholders together } \\
\text { to achieve regional economic } \\
\text { development goals }\end{array}$ & \\
\hline
\end{tabular}




\subsection{Specification of Lead To Win-Ottawa}

This section uses the framework provided in Section 4.1 to specify the existing venture-creation ecosystem denoted as Lead To Win-Ottawa. The notes that captured the information gained interviewing two people who are responsible for Lead To Win operations are provided as Appendix A.

\subsubsection{Sides of the Lead To Win-Ottawa business ecosystem}

Table 8 provides the 13 sides of the Lead To Win venture-creation ecosystem as of December 2015. Each stakeholder group comprises one side of the multi-sided framework. Participants in each side makes similar contributions to the platform and derive similar benefits.

For each side, Table 8 identifies the participants that comprise it; the cash, assets, and time and effort contributions they make; and the monetary and nonmonetary benefits they expect to derive. Table 8 draws from the interviews with three individuals who are part of the Lead To Win Council, six participants of Lead To Win, and the information provided by Muegge and Mezen (forthcoming, Table 4). 
Table 8: Sides of the Lead To Win business ecosystem

Side of multi-

sided

Participants

Contributions

Expected benefits platform

\begin{tabular}{|c|c|c|c|c|c|c|}
\hline & & Cash & Asset & $\begin{array}{l}\text { STime \& effort } \\
\text { to: }\end{array}$ & Monetary & $\begin{array}{l}\text { Non- } \\
\text { monetary }\end{array}$ \\
\hline $\begin{array}{l}1 \text { University of } \\
\text { which } \\
\text { keystone is a } \\
\text { part }\end{array}$ & Organization & Salaries & Space & $\begin{array}{l}\text { 1. Executive } \\
\text { support } \\
\text { 2. Support } \\
\text { raising funds } \\
\text { 3. Provide } \\
\text { backend } \\
\text { services } \\
\text { 4. Provide } \\
\text { feedback }\end{array}$ & $\begin{array}{l}\text { 1.External } \\
\text { funds } \\
2 . \text { Research } \\
\text { grants }\end{array}$ & $\begin{array}{l}\text { 1. Attract, } \\
\text { develop, and } \\
\text { retain } \\
\text { students, } \\
\text { faculty and } \\
\text { staff } \\
2 \text {. Enhance } \\
\text { brand and } \\
\text { reputation } \\
\text { 3. Attain } \\
\text { university's } \\
\text { objectives }\end{array}$ \\
\hline $\begin{array}{l}2 \text { Institute } \\
\text { responsible } \\
\text { for keystone }\end{array}$ & $\begin{array}{l}\text { Unit of large } \\
\text { organization }\end{array}$ & $\begin{array}{l}\text { 1. Stipends } \\
\text { 2. Salaries } \\
\text { and } \\
\text { contractor } \\
\text { fees } \\
\text { 3. Operating } \\
\text { expenses }\end{array}$ & Space & $\begin{array}{l}\text { 1. Lead } \\
\text { 2. Raise and } \\
\text { disburse funds } \\
\text { 3. Create } \\
\text { synergies with } \\
\text { academic } \\
\text { programs and } \\
\text { university's } \\
\text { priorities } \\
\text { 4. Provide } \\
\text { feedback }\end{array}$ & $\begin{array}{l}\text { 1.External } \\
\text { funds } \\
\text { 2. Research } \\
\text { grants }\end{array}$ & $\begin{array}{l}\text { 1. Learn by } \\
\text { doing, not } \\
\text { just talking } \\
2 . \text { Relevant } \\
\text { research, } \\
\text { teaching, } \\
\text { service } \\
\text { 3. Autonomy } \\
4 . \text { Attract, } \\
\text { develop, and } \\
\text { retain } \\
\text { students, } \\
\text { faculty and } \\
\text { staff } \\
5 \text {. Enhance } \\
\text { brand and } \\
\text { reputation }\end{array}$ \\
\hline $\begin{array}{l}3 \text { Suppliers of } \\
\text { government } \\
\text { grants to } \\
\text { organizations } \\
\text { that support } \\
\text { entrepreneurs }\end{array}$ & $\begin{array}{l}\text { Groups in } \\
\text { provincial and } \\
\text { federal } \\
\text { government } \\
\text { organizations }\end{array}$ & $\begin{array}{l}\text { Cash } \\
\text { contribution }\end{array}$ & & $\begin{array}{l}\text { 1. Coach } \\
\text { 2. Refer } \\
\text { entrepreneurs, } \\
\text { coaches, } \\
\text { service } \\
\text { providers } \\
\text { 3. Provide } \\
\text { feedback }\end{array}$ & $\begin{array}{l}\text { Cash match } \\
\text { to cash } \\
\text { contribution }\end{array}$ & $\begin{array}{l}\text { 1. In-kind } \\
\text { match to } \\
\text { cash } \\
\text { contribution } \\
2 . \text { Fulfill } \\
\text { contractual } \\
\text { requirements }\end{array}$ \\
\hline 4 Donors & Individuals & Internships & & $\begin{array}{l}\text { 1. Provide } \\
\text { feedback }\end{array}$ & & $\begin{array}{l}\text { 1. Legacy } \\
2 . \\
\text { Recognition }\end{array}$ \\
\hline
\end{tabular}


of personal

achievement

\begin{tabular}{|c|c|c|c|c|}
\hline 5 Entrepreneur & $\begin{array}{l}\text { S Individuals } \\
\text { who create } \\
\text { ventures }\end{array}$ & $\begin{array}{l}\text { 1. Create new } \\
\text { venture } \\
\text { 2. Meet Lead } \\
\text { To Win } \\
\text { objectives }\end{array}$ & Payment & $\begin{array}{l}\text { 1. Equity that } \\
\text { grows in } \\
\text { value } \\
2 . \\
\text { Emancipate } \\
\text { 3. Bring } \\
\text { about change } \\
\text { 4. Expand } \\
\text { network }\end{array}$ \\
\hline $\begin{array}{l}6 \text { LTW } \\
\text { Contractors }\end{array}$ & $\begin{array}{l}\text { Individuals or } \\
\text { small } \\
\text { business who } \\
\text { work for the } \\
\text { keystone }\end{array}$ & $\begin{array}{l}\text { 1. Provide } \\
\text { knowledge or } \\
\text { expertise } \\
\text { 2. Review } \\
\text { opportunities } \\
\text { 3. Make } \\
\text { referrals }\end{array}$ & Payment & $\begin{array}{l}\text { 1. Build own } \\
\text { business or } \\
\text { career } \\
2 \text {. Search for } \\
\text { strong } \\
\text { business } \\
\text { model } \\
\text { 3. Develop } \\
\text { skills } \\
\text { 4. Expand } \\
\text { network }\end{array}$ \\
\hline $\begin{array}{l}7 \text { Other local } \\
\text { post- } \\
\text { secondary } \\
\text { institutions }\end{array}$ & $\begin{array}{l}\text { Units of large } \\
\text { organizations } \\
\text { that deliver } \\
\text { services to } \\
\text { entrepreneurs }\end{array}$ & $\begin{array}{l}\text { 1. Enable } \\
\text { partnership } \\
\text { grants } \\
\text { 2. Deliver } \\
\text { services to } \\
\text { entrepreneurs } \\
\text { that } \\
\text { complement } \\
\text { LTW services } \\
\text { 3. Refer } \\
\text { entrepreneurs, } \\
\text { coaches, } \\
\text { service } \\
\text { providers }\end{array}$ & Payment & $\begin{array}{l}\text { 1. Attract, } \\
\text { develop, and } \\
\text { retain } \\
\text { students, } \\
\text { faculty and } \\
\text { staff } \\
2 . \text { Enhance } \\
\text { brand and } \\
\text { reputation } \\
3 . \text { Attain } \\
\text { post- } \\
\text { secondary } \\
\text { institutions' } \\
\text { objectives }\end{array}$ \\
\hline 8 Implementer & $\begin{array}{l}\text { Individuals } \\
\text { (e.g., } \\
\text { employees, } \\
\text { contractors, } \\
\text { advisors) who } \\
\text { build the } \\
\text { ventures' } \\
\text { offers }\end{array}$ & $\begin{array}{l}\text { 1. Build } \\
\text { venture's } \\
\text { offers }\end{array}$ & & $\begin{array}{l}\text { 1. Equity or } \\
\text { deferred } \\
\text { payment } \\
2 . \text { Develop } \\
\text { skills } \\
\text { 3. Work } \\
\text { experience4. } \\
\text { Expand } \\
\text { network }\end{array}$ \\
\hline
\end{tabular}




\begin{tabular}{|c|c|c|c|}
\hline $\begin{array}{l}9 \text { Settlement } \\
\text { and } \\
\text { integration } \\
\text { services }\end{array}$ & $\begin{array}{l}\text { Not for-profit } \\
\text { organizations }\end{array}$ & $\begin{array}{l}\text { 1. Refer } \\
\text { implementers } \\
\text { to } \\
\text { entrepreneurs }\end{array}$ & $\begin{array}{l}\text { 1. Place } \\
\text { clients in } \\
\text { jobs } \\
2 \text {. Increase } \\
\text { capacity to } \\
\text { attract } \\
\text { government } \\
\text { funding } \\
\text { 3. Enhance } \\
\text { brand and } \\
\text { reputation } \\
\end{array}$ \\
\hline $\begin{array}{l}10 \text { Service } \\
\text { providers }\end{array}$ & $\begin{array}{l}\text { Individuals } \\
\text { and } \\
\text { organizations } \\
\text { (e.g. } \\
\text { accountants, } \\
\text { lawyers, } \\
\text { marketing, } \\
\text { sales, } \\
\text { investors, } \\
\text { make venture } \\
\text { acquisition } \\
\text { ready) that } \\
\text { deliver } \\
\text { services } \\
\text { directly to } \\
\text { entrepreneurs }\end{array}$ & $\begin{array}{l}\text { 1. Review } \\
\text { opportunities } \\
\text { 2. Contribute } \\
\text { to in-kind } \\
\text { match } \\
\text { 3. Deliver } \\
\text { services } \\
\text { directly to } \\
\text { entrepreneurs } \\
\text { 4. Make } \\
\text { referrals } \\
\text { 5. Provide } \\
\text { knowledge and } \\
\text { expertise }\end{array}$ & $\begin{array}{l}\text { 1. Attract } \\
\text { new clients } \\
\text { 2. Shape } \\
\text { opportunities } \\
\text { 3. Expand } \\
\text { network } \\
\text { 4. Share } \\
\text { information } \\
\text { 5. Enhance } \\
\text { brand and } \\
\text { reputation } \\
\text { 6. Develop } \\
\text { skills } \\
\text { 7. Personal } \\
\text { satisfaction }\end{array}$ \\
\hline $\begin{array}{r}11 \text { Business } \\
\text { partners }\end{array}$ & $\begin{array}{l}\text { Individuals, } \\
\text { organizations } \\
\text { that supply, } \\
\text { complement, } \\
\text { integrate and } \\
\text { take to } \\
\text { market } \\
\text { ventures' } \\
\text { products and } \\
\text { services }\end{array}$ & $\begin{array}{l}\text { 1. Develop } \\
\text { ventures' } \\
\text { businesses } \\
\text { 2. Define } \\
\text { supply, } \\
\text { complement, } \\
\text { integration, go- } \\
\text { to-market } \\
\text { relationships } \\
\text { 3. Develop } \\
\text { complements } \\
\text { interdependent } \\
\text { with ventures' } \\
\text { products and } \\
\text { services }\end{array}$ & $\begin{array}{l}\text { 1. Access to } \\
\text { ventures } \\
\text { teams } \\
\text { 2. Act on } \\
\text { opportunities } \\
\text { 3. Recruit } \\
\text { talent }\end{array}$ \\
\hline 12 Early buyers & $\begin{array}{l}\text { Organizations } \\
\text { that purchase } \\
\text { ventures' } \\
\text { products and } \\
\text { services at an } \\
\text { early stage of } \\
\text { their life cycle }\end{array}$ & $\begin{array}{l}\text { 1. Provide } \\
\text { feedback }\end{array}$ & $\begin{array}{l}\text { 1. Gain } \\
\text { strategic } \\
\text { advantage } \\
\text { 2. Influence } \\
\text { product } \\
\text { development } \\
\text { 3. Learn }\end{array}$ \\
\hline
\end{tabular}


about new

technology

\begin{tabular}{clll}
\hline $\begin{array}{c}\text { 13 Economic } \\
\text { development }\end{array}$ & Government & 1.Enable & 1.Achieve \\
organizations & raising funds & regional \\
& and groups & 2. Link & economic \\
& responsible & entrepreneurs & development \\
& for regional & to & objectives \\
& economic & opportunities & 2. Attract \\
& development & 3. Link & capital, \\
& & keystone to & talent, \\
& & collaborative & business \\
& & & \\
\hline
\end{tabular}

\subsubsection{Platform}

The Lead To Win platform is a process platform that enables the sides identified in Table 8 to directly interact with one another. Each side is affiliated to the platform through the contributions it makes and the benefits it expects. The Lead To Win platform is conceptualized as being owned and operated by the Lead To Win Council, the keystone of the ecosystem.

The initiatives the Lead To Win platform supports are organized into nine components and 36 elements. Table 9 identifies the components and elements of the Lead To Win platform as well as the number of initiatives carried out for each element during 2015. The information in Table 9 was obtained from Bailetti (2015b, Appendix A). 
Table 9: Number of components and elements of the Lead To Win platform

\section{Lead To Win component}

1. Awards

2. Spark

\section{Incubate}

\section{Accelerate}

3.1 Technovation Challenge

3.2 Venture Demo Day

3.3 Opportunity review

3.4 Workshop

3.5 Sprint

3.6 Innovation in classroom

3.7 Coach

2.1 TIM Lecture

2.4 Brown bag lunch

2.5 Special topics
\# of initiatives carried out in 2015

1

1

1

0

Sub-total 3

$\begin{array}{cc} & 7 \\ & 6 \\ & 1 \\ & 8 \\ & 2 \\ \text { Sub-total } & 24\end{array}$

\begin{tabular}{|c|c|c|c|}
\hline & 4.1 Nicol internship & & 13 \\
\hline & 4.2 CLA stipend & & 20 \\
\hline & 4.3 Coach & & 0 \\
\hline & 4.4 Desk & & 2 \\
\hline & 4.5 Workshop & & 20 \\
\hline & 4.6 Market Intelligence Se & ice & 1 \\
\hline & 4.7 Partner showcase & & 2 \\
\hline & 4.8 Venture launch & & 5 \\
\hline & 4.9 Venture in the news & & 2 \\
\hline & & Sub-total & 65 \\
\hline 5. Sustain & 5.1 Plan & & 1 \\
\hline & & Sub-total & 1 \\
\hline 6. Invest & 6.1 Pitch & & 2 \\
\hline & & Sub-total & 2 \\
\hline $\begin{array}{l}\text { 7. Research, } \\
\text { Develop, \& Explore }\end{array}$ & 7.1 Refereed publication & & O \\
\hline & 7.2 TIM Review & & $\angle$ \\
\hline
\end{tabular}


7.3 TIM eBook

7.4 Project

8. Globalize

9. Improve

9 components
8.1 BigBlueButton

8.2 Cybersecurity

8.3 Global Resource

9.1 Intranet

9.2 Website

36 elements
Sub-total $\quad 14$

$\begin{array}{ll} & 4 \\ & 3 \\ \text { Sub-total } & 0 \\ & 7 \\ & 1 \\ \text { Sub-total } & 1 \\ & 2\end{array}$

173 initiatives

\subsubsection{Control direct interactions}

This section provides the results of examining the control over direct interactions. This section includes information on: i) control over contractual terms of direct interactions, and ii) number of members per stakeholder group.

Table 10 identifies whether or not Lead To Win controls the interactions among participants that occur around each of its 36 elements. The elements are organized by the nine components of Lead To Win.

A "Yes" in Table 10 means that the service is being provided by employees or contractors Lead To Win controls. This means that Lead To Win has control over the contractual terms of the interactions. A "No" means the service is being delivered by independent agents. This is consistent with the control definition advanced by Hagiu and Wright (2015b). The "Yes" or "No" were contributed by the Chair of the Lead To Win Council. 
Table 10: Control over interactions among participants

\section{Lead To Win element}

\section{Awards}

1.1 External funding award

1.2 Research award

1.3 Global award

1.4 Regional award

Spark

2.1 TIM Lecture

2.1 Featured event

2.3 Hackathon

2.4 Brown bag lunch

2.5 Special topics

Incubate

3.1 Technovation Challenge

3.2 Venture Demo Day

3.3 Opportunity review

3.4 Workshop

3.5 Sprint

3.6 Innovation in classroom

3.7 Coach

Accelerate

4.1 Nicol internship

4.2 CLA stipend

4.3 Coach

4.4 Desk

4.5 Workshop

4.6 Market Intelligence Service

4.7 Partner showcase

4.8 Venture launch

4.9 Venture in the news

Sustain

5.1 Plan

Invest

6.1 Pitch to investors

Research, develop, explore

7.1 Refereed publication

7.2 TIM Review

7.3 TIM eBook
Does LTW council controls contractual terms of interactions?

No

No

No

No

No

No

No

No

Yes

Yes

No

Yes

No

No

Yes

No

Yes

Yes

No

Yes

No

No

Yes

No

No

Yes

Yes

No

No

No 
7.4 Research project

Global

8.1 BigBlueButton

8.2 Cybersecurity

8.3 Global Resource

Improve

9.1 Intranet

9.2 Website
Yes

No

Yes

Yes

Yes

Yes

Table 11 provides the number of individuals or organizations that are part of each side of the multi-sided platform and whether or not this number is controlled by Lead To Win.

Table 11: Number of participants of each side and extent of control over the number of participants

\begin{tabular}{|c|c|c|c|}
\hline \multirow[t]{2}{*}{ Side of multi-sided platform } & \multicolumn{2}{|c|}{ Number of participants } & \multirow{2}{*}{$\begin{array}{c}\text { Limit on } \\
\text { number of } \\
\text { participants }\end{array}$} \\
\hline & Organizations & Individuals & \\
\hline University of which keystone is a part & 1 & 0 & Yes \\
\hline Institute responsible for keystone & 1 & 0 & Yes \\
\hline $\begin{array}{l}\text { Suppliers of government grants to } \\
\text { organizations that support entrepreneurs }\end{array}$ & 3 & 8 & No \\
\hline Donors & & 1 & No \\
\hline Entrepreneurs (venture teams) & 111 & NA & No \\
\hline LTW Contractors & & 5 & Yes \\
\hline Other local post-secondary institutions & 3 & & Yes \\
\hline Implementers & NA & NA & No \\
\hline Settlement and integration services & 1 & & No \\
\hline Service providers & 8 & 23 & No \\
\hline Business partners & NA & & No \\
\hline Early buyers & 2 & & No \\
\hline Economic development organizations & 2 & 12 & \\
\hline
\end{tabular}


The desired outcomes are measured in terms of:

- Sum of the annual sales of companies in the accelerator

- Sum of full time employees by companies in the accelerator

- Sum of the annual sales generated by companies launched over the last three years

- External funds attracted by the keystone 


\subsection{Selection of components for pragmatic reuse}

This section identifies the criteria that were used to select components from LTW-Ottawa for pragmatic reuse in LTW-Jordan. The selection of the components to reuse was based on the components' relative importance to Jordan and how easy they are to adapt for reuse in Jordan.

First, the researcher ranked LTW-Ottawa components based on their relative importance for Jordan. The components were organized into "must have", "nice to have", or "explore" according to their expected impact on the four challenges that face entrepreneurs in Jordan.

Afterwards, platform components that do not require special resources that do not exist in Jordan (e.g., stakeholders, knowledge, university program, etc.) and were considered easy to adapt and were selected for reuse in Jordan.

For the components that require special resources that do not exist in Jordan but have been ranked as "must have", the researcher checked the possibility to partner with LTW-Ottawa for the special resources. "Must have" components with possible partnership with LTW-Ottawa also were selected for reuse in Jordan. In summary, components of LTW-Ottawa that were selected for pragmatic reuse in Jordan are:

- Components that were considered easy to adapt.

- "Must have" components with possible partnership with LTW-Ottawa for the special resources. 


\subsection{Specification of Lead To Win-Jordan}

This section uses the framework provided in Section 4.1 and the components identified for reuse in Section 4.2 to build a new venture-creation ecosystem referred to as Lead To Win-Jordan. The notes that captured the information gained interviewing eight individuals who have knowledge about entrepreneurship in Jordan are provided as Appendix C. The researcher designed and used the semistructured interview protocol provided as Appendix B to conduct the interviews.

\subsubsection{Sides of the Lead To Win-Jordan business ecosystem}

Table 12 provides the 8 potential stakeholder groups of Lead To Win-Jordan that can provide contributions similar to the ones provided by Lead To Win-Ottawa stakeholders. Each stakeholder group comprises one side of the multi-sided framework. Potential participants in each side makes similar contributions to the platform.

For each side, Table 12 identifies the potential participants that comprise it; the expected cash, assets, and time and effort contributions they may make; and the expected monetary and non-monetary benefits they may derive. Table 12 draws from the interviews with the eight individuals who have knowledge about entrepreneurship in Jordan.

Interviewees were not able to identify potential participants for Lead To Win-Jordan to provide internships, knowledge or expertise as contractors with LTW, business partners for ventures or early buyers. In addition, interviewees were 
not able to identify expected benefits (value propositions) for almost half of the potential participants. However, they provided some general rules that may help identify value propositions for stakeholders in Jordan such as providing personal value to the key person other than the value to his organization, and mostly values should be short term as people care about the immediate results.

Table 12: Sides of the Lead To Win-Jordan business ecosystem

Side of multisided platform
Contributions Assets Time \& effort to:

1 Organization of Salaries which keystone is a part

$\begin{array}{ll}\text { Space } & \text { 1. Executive } \\ \text { support } \\ \text { 2. Support } \\ \text { raising fund } \\ \text { 3. Provide } \\ \text { backend } \\ \text { services } \\ \text { 4. Provide } \\ \text { feedback }\end{array}$

\section{Potential participants}

Expected benefits

Monetary Non-monetary

1. Public image, brand

\begin{tabular}{|c|c|c|}
\hline KADDB & & $\begin{array}{l}\text { 1. Public image, } \\
\text { brand }\end{array}$ \\
\hline Universities & $\begin{array}{l}\text { Tuition } \\
\text { fees }\end{array}$ & $\begin{array}{l}\text { 1. Public image, } \\
\text { brand } \\
\text { 2. Attract } \\
\text { students }\end{array}$ \\
\hline $\begin{array}{l}\text { Engineering } \\
\text { association }\end{array}$ & & $\begin{array}{l}\text { 1. Aligns with } \\
\text { their goals }\end{array}$ \\
\hline $\begin{array}{l}\text { Telecom } \\
\text { companies }\end{array}$ & & $\begin{array}{l}\text { 1. Find talents } \\
\text { 2. Generate } \\
\text { entrepreneurial } \\
\text { ideas for their } \\
\text { business } \\
\text { 3. PR }\end{array}$ \\
\hline
\end{tabular}

Existing

accelerators

Ministries

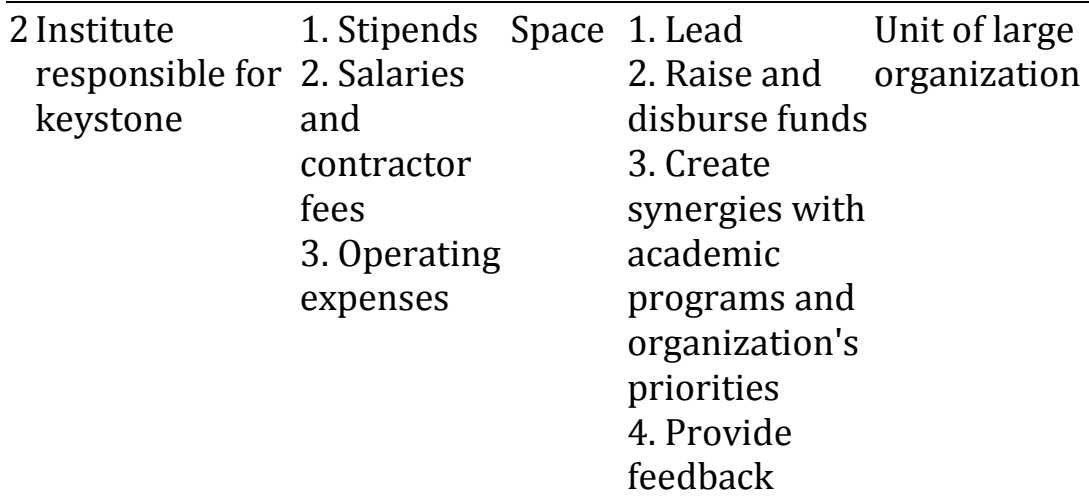




\begin{tabular}{|c|c|c|c|c|c|}
\hline \multirow{10}{*}{$\begin{array}{l}3 \text { Suppliers of } \\
\text { government } \\
\text { and non- } \\
\text { government } \\
\text { grants to } \\
\text { organizations } \\
\text { that support } \\
\text { entrepreneurs }\end{array}$} & \multirow[t]{10}{*}{$\begin{array}{l}\text { Cash } \\
\text { contribution }\end{array}$} & \multirow{10}{*}{$\begin{array}{l}\text { 1. Coach } \\
\text { 2. Refer } \\
\text { entrepreneurs } \\
\text { coaches, } \\
\text { service } \\
\text { providers } \\
\text { 3. Provide } \\
\text { feedback }\end{array}$} & $\begin{array}{l}\text { Engineering } \\
\text { association }\end{array}$ & & $\begin{array}{l}\text { 1. Aligns with } \\
\text { their goals }\end{array}$ \\
\hline & & & KADDB & & $\begin{array}{l}\text { 1. Public image, } \\
\text { brand }\end{array}$ \\
\hline & & & Endeavor & & $\begin{array}{l}\text { 1. Aligns with } \\
\text { their goals }\end{array}$ \\
\hline & & & $\begin{array}{l}\text { Talal Abu- } \\
\text { Ghazaleh } \\
\text { Organization }\end{array}$ & & 1. To give back \\
\hline & & & $\begin{array}{l}\text { Abd Al Hamid } \\
\text { Shoman } \\
\text { Foundation }\end{array}$ & & \\
\hline & & & Mowgli Jordan & & \\
\hline & & & $\begin{array}{l}\text { SDRF research } \\
\text { fund }\end{array}$ & & \\
\hline & & & $\begin{array}{l}\text { Arab Innovator } \\
\text { Network }\end{array}$ & & \\
\hline & & & $\begin{array}{l}\text { Ministry of } \\
\text { Labor }\end{array}$ & & \\
\hline & & & $\begin{array}{l}\text { Ministry of } \\
\text { Industry and } \\
\text { Trade }\end{array}$ & & \\
\hline 4 Entrepreneurs & & $\begin{array}{l}\text { 1. Create new } \\
\text { venture } \\
\text { 2. Meet Lead } \\
\text { To Win-Jordan } \\
\text { objectives }\end{array}$ & $\begin{array}{l}\text { Individuals } \\
\text { who create } \\
\text { ventures }\end{array}$ & $\begin{array}{l}1 . \\
\text { Payment } \\
\text { 2. Wealth } \\
\text { (build } \\
\text { companies } \\
\text { to flip) }\end{array}$ & $\begin{array}{l}\text { 1. Experience } \\
\text { to get jobs } \\
2 . \text { Record to } \\
\text { immigrate }\end{array}$ \\
\hline $\begin{array}{l}5 \text { Other local } \\
\text { entrepreneurial }\end{array}$ & & $\begin{array}{l}\text { 1. Enable } \\
\text { partnership }\end{array}$ & $\begin{array}{l}\text { Existing } \\
\text { accelerators }\end{array}$ & & \\
\hline inıtıatıves & & $\begin{array}{l}\text { grants } \\
\text { 2. Deliver } \\
\text { services to }\end{array}$ & INJAZ & & \\
\hline & & $\begin{array}{l}\text { entrepreneurs } \\
\text { that } \\
\text { complement }\end{array}$ & $\begin{array}{l}\text { Business } \\
\text { Development } \\
\text { Center } \\
\end{array}$ & & \\
\hline & & $\begin{array}{l}\text { LTW services } \\
\text { 3. Refer }\end{array}$ & $\begin{array}{l}\text { Startup } \\
\text { competitions }\end{array}$ & & \\
\hline & & $\begin{array}{l}\text { entrepreneurs } \\
\text { coaches, } \\
\text { service } \\
\text { providers }\end{array}$ & Endeavor & & $\begin{array}{l}\text { 1. Aligns with } \\
\text { their goals }\end{array}$ \\
\hline 6 Implementers & & $\begin{array}{l}\text { 1. Build } \\
\text { venture's } \\
\text { offers }\end{array}$ & $\begin{array}{l}\text { Students, fresh } \\
\text { graduates }\end{array}$ & & $\begin{array}{l}\text { 1. Get } \\
\text { experience to } \\
\text { immigrate }\end{array}$ \\
\hline
\end{tabular}




\begin{tabular}{|c|c|c|c|}
\hline $\begin{array}{l}7 \text { Employment } \\
\text { services }\end{array}$ & $\begin{array}{l}\text { 1. Refer } \\
\text { implementers } \\
\text { to } \\
\text { entrepreneurs }\end{array}$ & $\begin{array}{l}\text { Local } \\
\text { employment } \\
\text { websites: } \\
\text { akhtaboot.com; } \\
\text { bayt.com }\end{array}$ & \\
\hline \multirow[t]{2}{*}{$\begin{array}{l}8 \text { Service } \\
\text { providers }\end{array}$} & \multirow{2}{*}{$\begin{array}{l}\text { 1. Review } \\
\text { opportunities } \\
\text { 2. Contribute } \\
\text { to in-kind } \\
\text { match } \\
\text { 3. Deliver } \\
\text { services } \\
\text { directly to } \\
\text { entrepreneurs } \\
\text { 4. Make } \\
\text { referrals } \\
\text { 5. Provide } \\
\text { knowledge } \\
\text { and expertise }\end{array}$} & $\begin{array}{l}\text { Lawyers; } \\
\text { Accountants }\end{array}$ & $\begin{array}{l}\text { 1. Attract new } \\
\text { clients } \\
2 \text {. Expand } \\
\text { network } \\
\text { 3. Enhance } \\
\text { brand and } \\
\text { reputation }\end{array}$ \\
\hline & & $\begin{array}{l}\text { Old business } \\
\text { owners \& } \\
\text { entrepreneurs }\end{array}$ & $\begin{array}{l}\text { 1. Give back } \\
\text { 2. Reputation } \\
\text { 3. Find } \\
\text { potential } \\
\text { opportunities } \\
\text { to invest in }\end{array}$ \\
\hline
\end{tabular}

\subsubsection{Platform}

The Lead To Win-Jordan platform will reuse components and elements from the Lead To Win-Ottawa platform. The researcher selected the components based on the selection criteria for pragmatic reuse in section 4.3.

The researcher selected 23 out of 36 elements for reuse in Lead To WinJordan. These elements are organized into eight components. Table 13 identifies the selected components and elements of the Lead To Win-Jordan platform, their relative importance for Jordan, as well as the reason why each element was selected. 
Table 13: Components and elements of the Lead To Win-Jordan platform

\section{Platform Component}

1. Awards

2. Spark

3. Incubate

\section{Platform Element}

1.1 External funding award

1.2 Research award

1.3 Global award

1.4 Regional award

2.1 Featured event

2.2 Hackathon

2.3 Brown bag lunch

2.4 Special topics

3.1 Venture Demo Day

3.2 Opportunity review

3.3 Workshop

3.4 Sprint

3.5 Innovation in

classroom

3.6 Coach

4. Accelerate

4.1 Coach

4.2 Workshop

4.3 Venture launch

4.4 Venture in the news

5. Sustain

5.1 Plan

\section{Relative} importance

Nice to have

Nice to have

Nice to have

Nice to have

Explore

Explore

Explore

Explore

Explore

Must have

Must have

Explore

Nice to have

Must have

Must have

Must have

Nice to have

Nice to have

Must have

\section{Reason why selected}

Relatively easy to adapt

Relatively easy to adapt Relatively easy to adapt Relatively easy to adapt

Relatively easy to adapt Relatively easy to adapt Relatively easy to adapt Relatively easy to adapt

Relatively easy to adapt Relatively hard to adapt, but important and can partner with LTWOttawa for the criteria. Relatively hard to adapt, but important and can partner with LTW-

Ottawa for the workshop material / knowledge. Relatively easy to adapt Relatively easy to adapt

Relatively easy to adapt

Relatively easy to adapt Relatively hard to adapt, but important and can partner with LTWOttawa for the workshop material / knowledge. Relatively easy to adapt Relatively easy to adapt

Relatively hard to adapt, but important and can partner with LTWOttawa for the vision / knowledge. 


\begin{tabular}{|c|c|c|c|}
\hline 6. Invest & 6.1 Pitch & Must have & $\begin{array}{l}\text { Relatively hard to adapt, } \\
\text { but important and can } \\
\text { partner with LTW- } \\
\text { Ottawa for the criteria / } \\
\text { reviewers development. }\end{array}$ \\
\hline 7. Globalize & 7.1 Global resource & Must have & $\begin{array}{l}\text { Relatively hard to adapt, } \\
\text { but important and can } \\
\text { partner with LTW- } \\
\text { Ottawa for the } \\
\text { knowledge / access to } \\
\text { global market. }\end{array}$ \\
\hline 8. Improve & 8.1 Intranet & Explore & Relatively easy to adapt \\
\hline & 8.2 Website & Must have & Relatively easy to adapt \\
\hline
\end{tabular}

\subsubsection{Comparison between LTW-Ottawa and LTW-Jordan}

This section compares Lead To Win-Ottawa and Lead To Win-Jordan using the four defining features of the framework provided in section 4.1: sides, platform, control over direct interactions, and desired outcomes. Lead To Win-Jordan reuses the same desired outcomes and control over direct interactions used in Lead To Win-Ottawa. Differences between Lead To Win-Ottawa and Lead To Win-Jordan are mainly in sides and platform.

Lead To Win-Ottawa has 13 sides, while Lead To Win-Jordan has only 8 potential sides. The sides of Lead To Win-Jordan are less than the sides of Lead To Win-Ottawa because of the lack of potential stakeholders that can provide certain contributions such as business partners and early buyers. Also, the potential keystones for Lead To Win-Jordan are different than the keystone of Lead To WinOttawa, since there is high possibility to have a non-university based keystone in 
Lead To Win-Jordan.

In terms of platform, the Lead To Win-Jordan platform reuses only 8 components and 23 elements out of 9 components and 36 elements of the Lead To Win-Ottawa platform. This is because some components of the Lead To Win-Ottawa platform require special resources (that doesn't exist in Jordan) to be adapted for reuse in Jordan. Some of these elements are "Desks" which requires stakeholders that don't exist in Jordan, and "TIM Lectures” which require a university program that teaches entrepreneurship which doesn't exist in Jordan too.

\subsection{Plan to implement the Lead To Win-Jordan venture-creation ecosystem}

Based on the lessons learned about entrepreneurship in Jordan (Appendix D), lessons learned about multi-sided platforms launching tactics (Appendix E), and the specifications of Lead To Win-Jordan venture-creation ecosystem (Section 4.4) we develop the following implementation plan for Lead To Win Jordan:

Step 1:

The first step is to find a stakeholder who is able and willing to adopt Lead To Win Jordan as a keystone. This is because of the major role of the keystone in orchestrating all the processes and activities of the ecosystem. Given the collectivist culture in Jordan, the keystone should have power, influence, and respect in the country. 
Step 2:

In this step we propose to first implement the opportunity reviews focused on a niche, and building a group with common goal (Edelman, 2015). The niche is the opportunity reviews, and the common goal will be helping entrepreneurs validate their business opportunities.

Step 3:

To attract participants for the opportunity reviews, target places that gather people involved in entrepreneurship in one place (like competitions or any other events). This is a good way to attract large number of reviewers or entrepreneurs at once.

Step 4:

After building an image and a small community around the opportunity reviews, it is time to secure a political and financial support for the ecosystem to implement the other components. Finding an influencer or marquee participant (Edelman, 2015), will help raising money to fund the ecosystem operations.

Step 5:

After securing the ecosystem fund, start implementing the other elements of Lead To Win-Jordan platform. To do that use the basic zig-zag tactic (Evans, 2009) to build participation incrementally on each side, and reduce the commitment required for participation. 


\subsection{Method to design and implement a regional venture creation ecosystem that reuses components of another ecosystem}

By generalizing the steps carried out by this research, the researcher proposes the following method to reuse components of a regional venture creation ecosystem to design a venture creation ecosystem in a different region. The method is comprised of four steps:

Step 1:

Specify an existing regional venture-creation ecosystem by identifying its defining features: sides, platform, control over direct interactions, and desired outcomes.

Step 2:

Select components of the existing ecosystem platform for reuse in the new platform. In this research, we used the method developed in section 4.3 about pragmatic reuse of components.

Step 3:

Specify the new regional venture-creation ecosystem by identifying its defining features: sides, platform, control over direct interaction, and desired outcomes.

Step 4:

Use the launching tactics of multi-sided platforms to develop an 
implementation plan for the new venture-creation ecosystem to attract participation in the early stages.

\subsection{Summary}

This section provides the results of this exploratory research:

1. Framework to specify a business ecosystem

2. Specifications of the Lead To Win-Ottawa and Lead To Win-Jordan venture-creation ecosystems using the framework

3. Plan to implement the Lead To Win-Jordan venture-creation ecosystem

4. Method to design and implement a regional venture creation ecosystem that reuses components of another ecosystem 


\section{Discussion}

This chapter discusses the results of this exploratory research. Section 5.1 positions the framework used to specify Lead To Win-Ottawa and Lead To WinJordan as the first step toward an integrative model of business ecosystems. Section 5.2 identifies the specific issues that need to be addressed to fill the gap in the extant literature on how the components of a regional business ecosystem can be reused to build a new ecosystem to deliver similar outcomes in another region? Section 5.3 compares the results of this research with those reported by Muegge and Mezen (forthcoming). Section 5.4 discusses the proposed design of Lead To Win-Jordan. Section 5.5 discusses the implementation plan for Lead To Win-Jordan proposed in section 4.4. Section 5.6 discusses the proposed method to reuse the components of a regional venture creation ecosystem to design a venture creation ecosystem in a different region. Finally, Section 5.7 provides a summary of this chapter.

\subsection{Toward an integrative model of business ecosystems}

The results of reviewing the literature for the purpose of identifying defining features of business ecosystems provided in Chapter 2, suggest that these features evolved from five different perspectives or literature streams. Each focuses on somewhat different aspects of business ecosystems. However, the defining features from these streams offer complementary and overlapping insights into business ecosystems. 
The framework to specify an ecosystem that was proposed in Section 4.1 builds on the multi-sided platform perspective, one of the five that were identified in the literature. This framework specifies a business ecosystem in terms of four defining features: i) sides, ii) platform, iii) control over contractual terms of direct interactions, and iv) desired objectives. The first two features, sides and platform, have associated with the multi-sided platform perspective of business ecosystems since 2008. The third feature, control over contractual terms of direct interactions, is a business ecosystem feature that was recently introduced by Hagiu and Wright (2015a, b). The fourth feature, desired objectives, was first proposed by Bailetti (2010b). This feature seems to be more important to the specification of venturecreation business ecosystems that generate economic benefits for a region than to other business ecosystems.

The framework used to describe the two venture-creation business ecosystems in this study can be the first step towards developing an integrative model for business ecosystems. This model can benefit from considering other features for potential integration such as "risks due to interdependences with complements and adoption processes," "modularity," and "option value" (architecture of participation perspective); "ecosystem health" and "campaigns for ecological advancement" (biological perspective); and "interconnected institutional arrangements" and "feedback" (complex adaptive systems). 


\subsection{Specific issues that need to be addressed to fill the gap in the extant}

literature

An exploratory research approach was useful for identifying issues that need to be examined to fill the knowledge gap that motivated this study and defined the research question.

The research question was the following: How can components of a regional venture-creation ecosystem be reused to build an ecosystem designed to deliver similar outcomes in another region?

To make progress towards filling the knowledge gap, the researcher considers that at least the five following issues must be addressed:

1. Validate the framework for specifying business ecosystems that is proposed in this study

2. Define a hierarchy of platform features, components, and elements

3. Specify criteria to select and adjust components and elements for reuse

4. Identification of the steps of pragmatic methods to bring sides on board

5. Detail the method to pragmatically reuse components of existing business ecosystems to build new ones 


\subsection{Comparing results produced in this thesis with those reported by Muegge and Mezen (forthcoming)}

Muegge and Mezen (forthcoming) used five perspectives and information in Bailetti and Bot (2013) to describe Lead to Win. The results in section 4.1 of this thesis, specify Lead To Win as of the end of 2015 in terms of one perspective, the multi-sided platform perspective.

The goals, keystone, process platform approach, control over interactions of stakeholders groups, and most sides of Lead To Win seem to be the same. A comparison of the results reported in both studies suggests that the Lead To Win platform has evolved and additional stakeholder groups have been added. Seventeen new elements have been added to the Lead To Win platform to serve its goals. For example, in the knowledge and networking category, some important elements have been added such as workshops and investment readiness assessments. In the business development category, some new services have been added to help companies in the acceleration track such as the market intelligence services, company launches, and project portfolio. Also, new funding options have been added to the platform such as Carleton-Led Accelerator (CLA) grants, and events and connections with angel and international investors and seed accelerators. Finally, new strategic assets have been added to Lead To Win that include the cybersecurity hub, global resource, and the UBI-Global benchmarking. Six new stakeholder groups have been identified. Some of them are not new but were not reported by Muegge and Mezen (forthcoming) as stakeholder groups such 
as the keystone, Lead To Win contractors, and donors. Other new stakeholder groups identified are settlement and integration service.

Lead To Win is a process platform that includes different types of elements such as processes (e.g., opportunity reviews and investor pitches), people (e.g., coaches and the global resource), and services (e.g., access to desks and market intelligence services), and infrastructure (e.g., BigBlueButton, the Lead To Win intranet, and websites). There is no specific hierarchy for elements that comprise a process platform. Elements of Lead To Win were reported in this research in the same hierarchy provided by Lead To Win.

\subsection{Design of Lead To Win-Jordan}

The proposed design of Lead To Win-Jordan reuses the same desired outcomes and control over direct interactions used in Lead To Win-Ottawa. However, it reuses only 23 out of 36 of Lead To Win-Ottawa platform elements, it has different stakeholders with different value propositions, and most probably will have a non-university based keystone. There could be a challenge in implementing some of the platform elements in Jordan. For example, finding coaches with the right entrepreneurial knowledge and skills to teach in the bootcamp or workshops elements could be a challenge. Cutting-edge entrepreneurial knowledge is a differentiator for Lead To Win-Ottawa, therefore, making sure that the sources of entrepreneurial knowledge for Lead To Win-Jordan are legitimate and up-to-date is essential. One solution for this issue could be partnering with Lead To Win-Ottawa either to provide coaches or at least course materials for the training sessions. 
Another challenge is implementing the university-level business courses element. There are business schools in Jordan, but none of them teach entrepreneurship. Partnering with TIM program to create courses or even university programs for entrepreneurship could be a solution. Interviewees were not able to identify potential stakeholders to be operational partners or early adopters. They also were not able to identify investment experts that could help identify ready for investment opportunities. Looking for global partners that can fill these gaps could be a solution. Interviewees were not able to identify specific expected benefits for almost half of the potential stakeholders. However, they provided some general rules that may help identifying expected benefits for stakeholders in Jordan such as providing personal value to the key person other than the value to his organization. Also, mostly expected benefits should be short term as people care more about the immediate results.

Of the six potential keystones for Lead To Win-Jordan identified by interviewees, five of them are not universities. Having a non-university keystone could be an advantage and a disadvantage. It may be an advantage because some of these non-university keystones have the ability to fund the ecosystem such as KADDB, telecom companies, and the engineering association. However, it also could be a disadvantage since there will not be direct interaction with up-to-date knowledge generated by academic institutions.

The fact that Lead To Win is operating successfully in one region does not necessarily mean it will operate successfully in another region; intercultural 
differences between the two regions may be important (Hofstede, 2010). In this research, the inter-cultural differences between Ottawa and Jordan are assumed to be reflected in the selection of the platform components for pragmatic reuse and the investments and expected benefits that define the affiliation of the sides to the platform of the business ecosystem. An important question is not explored here: what are the cultural differences that need to be considered that are not reflected in these two factors? This question could be a potential area for future research.

Finally, the proposed design of Lead To Win-Jordan makes assertions that need to be validated. It provides an advanced starting point for people interested in implementing Lead To Win-Jordan to start the experimentation. 


\subsection{Implementation plan for Lead To Win-Jordan}

The proposed plan for Lead To Win-Jordan builds on the lessons learned from the literature about launching multi-sided platforms. Unfortunately, the researcher found only two studies that were relevant to bring stakeholder groups on board (Evans, 2009; Edelman, 2015). Richer literature would have resulted in better and more options for the implementation plan. This is important high-impact area for future research,

\subsection{Method to design and implement a regional venture creation ecosystem that reuses components of another ecosystem}

The proposed method is somehow high level. It does not provide a specific way to capture the data about an ecosystem or its stakeholders. Also, there are no specific steps to follow to create an implementation plan other than combining the knowledge about the new region with the tactics of launching multi-sided platforms. In addition, to be able to use this method, it requires an understanding for the four components of the framework identified in section 4.1. Overall, however, it provides a useful starting point to propose a design of an ecosystem that can be used as starting point for experimentation.

\subsection{Summary of Chapter 5}

Chapter 5 discusses the results of the research. This chapter proposes that the framework to specify business ecosystem identified in this research be the first step towards an integrative model for business ecosystems. While the proposed 
framework is aligned with the multi-sided platform perspective, the researcher considers that there is value in examining defining features examined in the other four perspectives identified in the literature reviewed presented in chapter 2 .

This chapter identified five issues that need to be examined to fill the knowledge gap that motivated this research: i) validate the framework for specifying business ecosystems that is proposed in this study, ii) define a hierarchy of platform features, components, and elements, iii) specify criteria to select and adjust components and elements for reuse, iv) identification of the steps of pragmatic methods to bring sides on board, and v) detail the method to pragmatically reuse components of existing business ecosystems to build new ones.

This chapter also provided a comparison of the results reported here and those of Muegge and Mezen (forthcoming), the specification of Lead To Win-Jordan, and a general method to enable the reuse of business ecosystem components. 


\section{Conclusions, Limitations, and Suggestions for Future Research}

\subsection{Conclusions}

This research began by noting a gap in the literature on business ecosystems: lack of a method to select, adapt and integrate components of existing ecosystems to build a new ecosystem. The research question was the following: How can components of a regional venture-creation ecosystem be reused to build an ecosystem designed to deliver similar outcomes in another region?

The research required the identification of the defining features of business ecosystems, the specification of an existing business ecosystem, the design of a new ecosystem in a very different geographical region, and the development of criteria for selecting the ecosystem components that can be reused to build the new ecosystem.

The research was applied to produce a design and a plan for a venturecreation ecosystem in Jordan (Lead To Win-Jordan) that could reuse the components of the existing venture-creation ecosystem (Lead To Win-Ottawa).

This research has four conclusions. First, a business ecosystem can be specified using four defining features: i) stakeholder groups, ii) platform, iii) control over contractual terms of direct interactions, iv) desired outcomes. These defining features can be used to characterize existing ecosystems and the search for the design of new business ecosystems. 
Second, this research concludes that there is a need to develop criteria to select, adapt and integrate components of existing ecosystems for pragmatic reuse and that the literature on code reuse can be leveraged for this purpose.

Third, this research concludes that the multi-sided platform and architecture of participation perspectives on business ecosystems are converging. The multisided platform perspective offers a top down view of a business ecosystem, while the architecture of participation offers a bottom-up view of the same phenomenon. This supports the arguments of Gawer (2014) and ongoing work to develop new theory to unify these perspectives.

Fourth, this research concludes that there can be significant benefits in gaining a better understanding on how to design and operate a venture-creation ecosystem that delivers regional economic benefits.

The design of Lead To Win-Jordan is more comprehensive and consistent than other initiatives that support entrepreneurs in Jordan, and unique in terms of its goals and principles. Unlike other entrepreneurship initiatives in Jordan, Lead To Win-Jordan provides an acceleration program for ventures without making claims over intellectual property or equity. Its acceleration program provides a legitimate source of entrepreneurial knowledge, enables ventures go global from day one, and educates entrepreneurs about investments and how to deal with investors. Implementing the proposed design will add a new perspective on supporting entrepreneurs which will make a difference in Jordan. 
In addition, if you are an individual or an organization responsible for creating regional venture-creation ecosystems, you no longer have to design ecosystems from scratch or naïvely emulate other ecosystems. Instead, you can selectively and deliberately reuse the components of Lead To Win-Ottawa from this research, or you can use the four-step method to specify another ecosystem you deem to be successful and reuse components from that ecosystem in a new design your region. There are other successful venture-creation ecosystems with knowledge and experience; the question is, can you benefit from their experience to build a venture-creation ecosystem for your region that one day can outperform the original system?

\subsection{Limitations}

This research has at least three limitations. First, to use the four-step method effectively, there should be criteria to decide which components of the existing venture-creation ecosystem to include in the new design of a venture-creation ecosystem in a different region. Such criteria do not exist in the literature. When creating the design of Lead To Win-Jordan, the researcher decided to include the components of Lead To Win-Ottawa that directly impact the challenges that face entrepreneurs in Jordan. It is not clear if this is the right criteria to use.

Second, this research proposes a design for Lead To Win-Jordan, but does not implement the design. This leaves unanswered questions about the quality and value of the resulting design. Implementing the design will provide data about the quality and value of the design. 
Third, this research does not explicitly consider cultural differences between Ottawa and Jordan and how those differences might impact the proposed design of Lead To Win-Jordan, its implementation, or its success likelihood.

\subsection{Suggestions for future research}

This research proposes seven areas for future research. First, future research should develop a playbook on how to build and evolve a venture-creation ecosystem using the design science approach.

Second, future research should examine the different phases of the evolution of Lead To Win-Ottawa (and other venture creation ecosystems) and compare those phases against the business ecosystem life cycle proposed by Moore (1993).

Third, future research should refine and improve the method proposed here, particularly the criteria to use to select, adjust, and integrate components of business ecosystems.

Fourth, future research should empirically validate if the method used here for venture-creation ecosystems anchored around a process platform also applies to business ecosystems and platforms of other types.

Fifth, future research should examine whether or not the method used to build Lead To Win-Jordan using Lead To Win-Ottawa components also applies to building Lead To Win in other regions. 
Sixth, future research should examine whether or not the method used to build Lead To Win-Jordan using Lead To Win-Ottawa also applies to building an ecosystem using components from multiple ecosystems.

Seventh, future research should examine how cultural differences affect the design and implementation of a regional venture-creation ecosystem that reuses components from another regional ecosystem. 


\section{References}

Adner R. 2006. Match your innovation strategy to your innovation ecosystem. Harvard Business Review. 84(4): 98-107.

Adner R, \& Kapoor, R. 2010. Value creation in innovation ecosystems: How the structure of technological interdependence affects firm performance in new technology generations. Strategic Management Journal. 31(3): 306-333.

Anderson, J. C., Narus, J. A., \& van Rossum, W. 2006. Customer value propositions in business markets. Harvard Business Review, 84(3): 90.

Bailetti, T. 2010a. Technical entrepreneurs benefits from business ecosystem. Open Source Business Resource, February. http://timreview.ca/article/325.

Bailetti,, T. 2010b. Blueprint and approach to grow revenue in small technology companies. Open Source Business Resource, June. http://timreview.ca/article/355.

Bailetti, T. 2010c. Keystone off-the-shelf. Open Source Business Resource, September. http://timreview.ca/article/377.

Bailetti, T. 2015a. Opportunity Reviews. A welcoming presentation presented at Lead To Win opportunity review event at Carleton University, Ottawa, Canada.

Bailetti, T. 2015b. Lead To Win in the Online Media. Unpublished document produced by Lead To Win, Ottawa, Canada.

Bailetti, T., \& Bot, S. 2013. An ecosystem-based job-creation engine fuelled by technology entrepreneurs. Technology Innovation Management Review, 3(2):31-40. http://timreview.ca/article/658.

Bailetti, T., \& Hudson, D. 2009. Value Co-creation: Lessons from Lead to Win Ecosystem. Open Source Business Resource, December. http://timreview.ca/article/308.

Bailetti, T., \& Prattico, L. 2011. Carleton Entrepreneurs: The First Keystone Off-TheShelf Application. Open Source Business Resource, April. http://timreview.ca/article/433.

Baldwin, C. Y., \& Clark, K. B. 2000. Design rules: The power of modularity. Cambridge, Mass: MIT Press.

Baldwin, C. Y. \& Clark, K. B. 2006. The architecture of participation: Does code architecture mitigate free riding in the open source development mode?. Management Science, 52(7):1116-1127. 
Boudreau, K. 2010. Open platform strategies and innovation: Granting access vs. devolving control. Management Science, 56(10): 1849-1872.

Boudreau, K. J., \& Hagiu, A. 2009. Platform rules: Multisided platforms as regulators. In A. Gawer (ed.), Platforms, Markets, and Innovation, Northampton, MA: Edward Elgar: 163-191.

Brown, R. B., 2006. Doing Your Dissertation in Business and Management: The Reality of Research and Writing, Sage Publications.

Edelman, B. 2015. How to launch your digital platform: A playbook for strategists. Harvard Business Review, 93(4): 90-97.

Eisenmann, T., Parker, G., \& Alstyne, M. V. 2006. Strategies for two-sided markets. Harvard Business Review, 84(10): 92-101.

Evans, D. S. 2009. How catalysts ignite: the economics of platform-based start-ups. In A. Gawer (ed.), Platforms, Markets, and Innovation, Northampton, MA: Edward Elgar: 99-128.

Evans, D. S., Hagiu, A., \& Schmalensee, R. 2008. Invisible Engines. MIT Press.

Gawer, A. 2009. Platforms, markets and innovation. Cheltenham, UK: Edward Elgar.

Gawer, A. 2014. Bridging differing perspectives on technological platforms: Toward an integrative framework. Research Policy, 43(7): 1239-1249.

Gawer, A., \& Cusumano, M. A. 2014. Industry platforms and ecosystem innovation. Journal Of Product Innovation Management, 31(3): 417-433.

Hagiu, A. 2009. Two-sided platforms: product variety and pricing structures. Journal of Economics \& Management Strategy, 18(4): 1011-1043.

Hagiu, A. 2014. Strategic decisions for multisided platforms. MIT Sloan Management Review, 55(2): 71-82.

Hagiu, A., \& Wright, J. 2015a. Multi-sided platforms. International Journal of Industrial Organization, 43: 162-174.

Hagiu, A., \& Wright, J. 2015b. Enabling Versus Controlling. Harvard Business School: Working Paper, 16-002.

Hagiu, A., \& Wright, J. 2015c. Marketplace or reseller? Management Science, 61(1), 184-203. doi:10.1287/mnsc.2014.2042

Hofstede GH, Hofstede GJ, Minkov M. 2010. Cultures and organizations: software of the mind: intercultural cooperation and its importance for survival. 3rd rev. ed. New York: McGraw-Hill. 
lansiti, M., \& Levien, R. 2002. The new operational dynamics of business ecosystems: Implications for policy, operations and technology strategy. Harvard Business School: Working Paper, 03-030.

Iansiti, M. \& Levien, R. 2004. Strategy as ecology. Harvard Business Review, 82(3): 68-78.

Isenberg, D. J. 2010. How to start an entrepreneurial revolution. Harvard Business Review, 88(6): 40-50.

Iyer B, Davenport TH. 2008. Reverse engineering: Google's innovation machine. Harvard Business Review. 86(4), 58-68.

Kessel M, Atkinson C. 2015. Ranking Software Components for Pragmatic Reuse. IEEE.

Makienko J, Misaka A. 2011. A Progress Report on the Keystone Off-The-Shelf Project. Open Source Business Resource, April. http://timreview.ca/article/432.

Mezen, M., \& Carleton University. 2014. Business ecosystems and new venture business models: An exploratory study of participation in the lead to win job-creation engine. Theses and Dissertations. Engineering, Technology Innovation Management. Ottawa.

Moore, J. F. 1993. Predators and prey: a new ecology of competition. Harvard business review, 71(3): 75-86.

Moore, J. F. 1996. The death of competition: Leadership and strategy in the age of business ecosystems. New York: Harper Business.

Moore, J. F. 2006. Business ecosystems and the view from the firm. The Antitrust Bulletin, 51(1): 31-75.

Muegge, S. 2011a. Business ecosystems as metaphor, label, and analogy. Presented at the Academy of Management 2011 Annual Meeting (AoM 2011, August 12-16, San Antonio, Texas).

Muegge, S. 2011b. Business Ecosystem as Institution of Participation: a systems perspective on community-developed platforms. Technology Innovation Management Review, November: 4-13. http://timreview.ca/article/495.

Muegge, S. 2013. Platforms, communities, and business ecosystems: Lessons learned about technology entrepreneurship in an interconnected world. Technology Innovation Management Review, 3(2): 5-15. 
Muegge, S. M., \& Mezen, M. 2016 (forthcoming). Business ecosystems and new venture business models: An exploratory study of participation in the Lead to Win job-creation engine. International Journal of Technology Management.

Parker, G.G. \& Van Alstyne, M.W. 2005. Two-sided network effects: a theory of information product design-related. Management Science, 51(10): 14941504.

Rochet, J.C. \& Tirole, J. 2003. Platform competition in two-sided markets. Journal of the European Economic Association, 1(4): 990-1029.

Rochet, J.C. \& Tirole, J. 2006. Two-sided markets: a progress report. RAND Journal of Economics, 37(3): 645-667.

Rong, K., \& Shi, Y. 2015. Business ecosystems: Constructs, configurations, and the nurturing process. New York, NY: Palgrave Macmillan.

Rong, K, Hu, G., Lin, Y., Shi, Y., \& Guo, L. 2015. Understanding business ecosystem using a 6C framework in Internet-of-Things-based sectors. International Journal of Production Economics. 159: 41-55.

Rosemann M, Brocke Jv,. 2010. Handbook on Business Process Management: Introduction, Methods and Information Systems. Berlin: Springer.

Schmidt, J., \& Keil, T. 2013. What makes a resource valuable? identifying the drivers of firm-idiosyncratic resource value. Academy of Management Review, 38(2), 206-228.

Simon, H. A. 1969. The sciences of the artificial. Cambridge: M.I.T. Press.

Singh, K, 2007, Quantitative Social Research Methods, SAGE Publications.

Thomas, L. D. W., Autio, E., \& Gann, D. M. 2014. Architectural leverage: Putting platforms in context. Academy of Management Perspectives, 28(2): 198219.

UBI-Global. 2015. Top University Business Incubators - Global Benchmark 15/16.

West, J. \& O'Mahony, S. 2008. The role of participation architecture in growing sponsored open source communities. Industry and Innovation, 15(2): 145168.

Wyne, J. 2014. The next step: Breaking the barriers to scale for MENA's entrepreneurs. Wamda Research Lab.

Wyne, J. 2015. Country Insights: Exploring trends and challenges in to scale for startups in Egypt, Jordan, Lebanon and the UAE. Wamda Research Lab. 
Yin RK. 1989. Case Study Research: Design and Methods. Newbury Park, CA: Sage Publications. 


\section{Appendices}

Appendix A: Summary of responses from interviews with two individuals core to the operations of Lead To Win

\section{Lead To Win principles:}

1. Provides many free services while making progress towards generating $\$ 1$ M/year revenue for a business that YOU own - takes no equity position or makes claims on intellectual property

2. Enables rapid globalization early

3. Reduces time-to-cash

4. Helps develop "something" for which customers are willing to pay, help improve, and refer to others

5. Supports stakeholders' network anchored on venture

6. Applies research and practical experience to improve likelihood of venture's success

7. Enhances capacity to sell to first customers, raise funds, and attract and retain talent

\section{Lead To Win components:}

- Spark

- TIM lectures

- Technovation Challenge: Entrepreneurial competition that teaches high school girls the basics of programming, how to develop a mobile 
application concept, business model, and a prototype.

- Featured events

- Hackathons

- Brown launches

- Incubate

- BSUI \& TIM courses: Academic courses from the Sprott School of Business and Technology Innovation Management (TIM) program at Carleton University. These courses cover different topics in business, entrepreneurship and innovation.

- Venture Demo Days: Venture demo days are showcase events organized to enable students enrolled in entrepreneurship courses at Carleton University present their early stage business ideas.

- Carleton-Led Accelerator (CLA) Ready

- Workshops: Workshops designed for entrepreneurs to convey knowledge, develop skills, and advance the business.

- Sprints

- Coaches

- Wall1: Opportunity assessments

- Accelerate

- Coaches

- Nicol Internships

- CLA grants: Grants provided to entrepreneurs enrolled in Carleton-led accelerator. 
- Space in accelerator

- Desks: sales, ICT, progress

- Workshops

- Market Intelligence Services: Entrepreneurs with green rated opportunities get access to market intelligence reports from wellknown market research companies. This service is provided by an economic development organization that is partner to LTW.

- Partner showcases: Showcase events organized with different partners, especially from the government, to help entrepreneurs find early buyers and identify business opportunities in the local market.

- Company launches: LTW organizes official launch events for companies with green rated opportunities. Also, LTW issues press releases about the company launches.

- 3-6 months placements with incubators abroad: Program to place entrepreneurs in incubators outside Canada for 3-6 months to help them explore the global market, and identify business opportunities and partners.

- Sustain

- Student consulting

- PD program: Professional development program for employees of established businesses.

- Wall2: Investment readiness assessments: To validate opportunities readiness for investment, entrepreneurs first present to a panel of external 
reviewers with investment expertise.

- Investor

- Y Combinator, Founders Fuel: Seed accelerator that provide early stage seed funding for startups.

- Axis Ottawa: An event organized by partners of LTW to connect entrepreneurs with international investors.

- Angels: Networks of angel investors that provide early stage investments for startups.

- $\mathrm{R}, \mathrm{D}$, \& $\mathrm{E}$

- TIM Review

- Project portfolio: Companies can benefit from the knowledge and expertise of TIM faculty and students to conduct research, development, and experimentation projects.

- Top Talent Academy

- Globalize

- BigBlueButton: Not-for-profit organization designed to enhance the value of remote student's academic experiences and reduce the cost of institutions responsible for delivering these experience, through the development, administration and management of an open source web-conferencing system (http://bigbluebutton.org).

- Cybersecurity hub: Non-profit organization designed to make Canada a leader in cybersecurity. It helps its members work on complex, leading-edge cybersecurity problems affecting individuals, businesses 
and governments throughout the world.

- Global Resource: Network of over 200 of TIM program alumni from all over the world who provide entrepreneurs with market information and business opportunities in their countries.

- Improve

- Design science approach: ecosystem co-evolution approach

- UBI-Global benchmarking: Global benchmarking program for business incubators around the world. LTW incubator has been ranked among the top ten university business incubators in North America. (UBIGlobal, 2015)

Table 14: Lead To Win-Ottawa stakeholders - interviews responses

\begin{tabular}{|c|c|c|}
\hline LTW Stakeholders & Contributions & Value propositions \\
\hline 111 Venture teams & - Lead ventures creation & $\begin{array}{ll}\text { - } & \text { Independence } \\
\text { - } & \text { Passion } \\
\text { - } & \text { Wealth }\end{array}$ \\
\hline 8 Service providers & $\begin{array}{l}\text { - Reviewers } \\
\text { - Coaches }\end{array}$ & $\begin{array}{l}\text { Promote their } \\
\text { services }\end{array}$ \\
\hline $\begin{array}{l}12 \text { People from } \\
\text { economic } \\
\text { development } \\
\text { organizations }\end{array}$ & $\begin{array}{l}\text { - Reviewers } \\
\text { - Coaches } \\
\text { - Grants } \\
\text { - Investment readiness } \\
\text { assessment }\end{array}$ & $\begin{array}{l}\text { - Brand Ottawa as } \\
\text { the most innovative } \\
\text { city in Canada } \\
\text { - } \text { Easy to find right } \\
\text { companies to } \\
\text { support }\end{array}$ \\
\hline
\end{tabular}




\begin{tabular}{|c|c|c|}
\hline & & $\begin{array}{l}\text { Reduce time } \\
\text { wanted in coaching } \\
\text { companies }\end{array}$ \\
\hline $\begin{array}{l}13 \text { Serial } \\
\text { entrepreneurs }\end{array}$ & $\begin{array}{l}\text { - Reviewers } \\
\text { - } \text { Coaches }\end{array}$ & 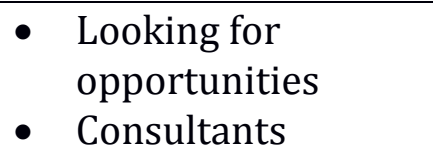 \\
\hline $\begin{array}{l}5 \text { Large company } \\
\text { people }\end{array}$ & $\begin{array}{l}\text { - } \text { Reviewers } \\
\text { - } \text { Coaches }\end{array}$ & $\begin{array}{l}\text { - Stay active in the } \\
\text { space } \\
\text { - Networking } \\
\text { - Looking for } \\
\text { opportunities }\end{array}$ \\
\hline 3 Retired people & $\begin{array}{ll}\text { - } & \text { Reviewers } \\
\text { - } & \text { Coaches }\end{array}$ & 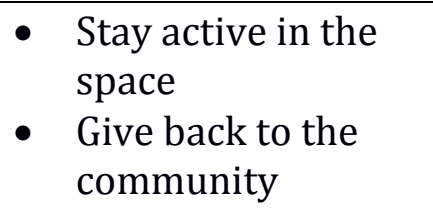 \\
\hline $\begin{array}{l}2 \text { Business } \\
\text { Development Bank } \\
\text { (BDC) }\end{array}$ & $\begin{array}{ll}\text { - } & \text { Reviewers } \\
\text { - } & \text { Coaches } \\
\text { - } & \text { Investment readiness } \\
& \text { assessment }\end{array}$ & $\begin{array}{l}\text { - Look for new } \\
\text { companies to invest } \\
\text { in }\end{array}$ \\
\hline 3 Lead To Win staff & - Run LTW operations & $\begin{array}{ll}\text { - } & \text { Learning / Skill } \\
\text { development } \\
\text { - } & \text { A bit of Money } \\
\text { - } & \text { Brand } \\
\text { - } & \text { Network }\end{array}$ \\
\hline $\begin{array}{l}\text { Employees work for } \\
\text { the companies }\end{array}$ & - Build companies & $\begin{array}{ll}\text { - } & \text { Learning / Skill } \\
& \text { development } \\
\text { - } & \text { Expand network }\end{array}$ \\
\hline
\end{tabular}




\begin{tabular}{|c|c|c|}
\hline $\begin{array}{l}\text { Leads and employees } \\
\text { of Lead To Win desks }\end{array}$ & $\begin{array}{l}\text { Lead of sales desk: } \\
\text { - Selects and trains students } \\
\text { - } \quad \text { Credo sell for the companility } \\
\text { Lead of ICT desk: } \\
\text { - Tech support to LTW }\end{array}$ & $\begin{array}{ll}\text { - } & \text { Legitimacy } \\
\text { - } & \text { Money }\end{array}$ \\
\hline Donors & - Money & $\begin{array}{ll}\text { - } & \text { Personal } \\
& \text { achievement } \\
\text { - } & \text { Legacy }\end{array}$ \\
\hline Complementors & $\begin{array}{l}\text { - To Provide services to } \\
\text { companies }\end{array}$ & $\begin{array}{ll}\text { - } & \text { To earn money } \\
\text { - } & \text { Development and } \\
\text { business skills }\end{array}$ \\
\hline MARs & - Provide market research & $\begin{array}{l}\text { It is in their } \\
\text { mandate to foster } \\
\text { companies growth }\end{array}$ \\
\hline City of Ottawa & $\begin{array}{l}\text { Identifying business } \\
\text { opportunities for startups } \\
\text { in the local market }\end{array}$ & $\begin{array}{l}\text { - To create jobs } \\
\text { - Brand the city as a } \\
\text { technology center } \\
\text { - Create revenue for } \\
\text { the city }\end{array}$ \\
\hline $\begin{array}{l}\text { Capital Angel } \\
\text { Network }\end{array}$ & - Angle capital & $\begin{array}{ll}\text { - } & \text { Return on } \\
& \text { investment }\end{array}$ \\
\hline $\begin{array}{l}\text { Y-Combinator, } \\
\text { Founder Fuel }\end{array}$ & - Seed capital & $\begin{array}{ll}- & \text { Return on } \\
& \text { investment }\end{array}$ \\
\hline Axis-Ottawa & - Venture capital & $\begin{array}{ll}- & \text { Return on } \\
& \text { investment }\end{array}$ \\
\hline TIM Alumni & - Market information & $\begin{array}{l}\text { - } \text { Pay back } \\
\text { - Opportunity to } \\
\text { make Money }\end{array}$ \\
\hline
\end{tabular}




\begin{tabular}{|c|c|c|}
\hline TIM Program & $\begin{array}{ll}\text { - } & \text { Knowledge \& courses } \\
\text { - University resources } \\
\text { - }\end{array}$ & $\begin{array}{ll}\text { - } & \text { Learning by doing } \\
\text { - } & \text { Differentiation } \\
\text { - } & \text { Attract students \& } \\
\text { money } \\
\text { - } \\
\text { Identify research } \\
\text { opportunities }\end{array}$ \\
\hline $\begin{array}{l}\text { InTac, Business } \\
\text { schools }\end{array}$ & - Access to a pool of talents & $\begin{array}{l}\text { - Value to their } \\
\text { network of talents }\end{array}$ \\
\hline
\end{tabular}


Appendix B: Semi-structured interview protocol for individuals that have

knowledge about entrepreneurship in Jordan

Research ethics protocol number: 15-221

Population: Individuals that have knowledge about entrepreneurship in Jordan.

Sample: Eight individuals that have knowledge about entrepreneurship in Jordan

with diverse roles. The researcher is from Jordan and will leverage his connections to recruit participants.

\section{B.1 Recruitment Email:}

To:

Cc:

Subject:

Hello,

I would like to invite you to participate in a research project entitled: "Design of a Regional Venture-Creation Ecosystem by Reusing the Components of Another Ecosystem". This research reuses the principles and components of Canada's Lead to Win Job-Creation Engine to implement similar ecosystem in Jordan to fulfill the academic requirements for the Technology Innovation Management program at Carleton University. The principal investigator for this research project is myself, Abdallah Sunna, a graduate student in Technology Innovation Management (TIM) program at Carleton University in Ottawa, Canada. The research is supervised by Professor Steven Muegge of the Sprott School of Business.

\section{Overview of the research project}

Lead To Win (http://www.leadtowin.ca) is a successful business ecosystem designed to be a job-creation engine in Canada's capital region. It supports entrepreneurs to create startups and employment in the region. This research reuses the principles and components of Lead to Win to propose a design for a venture creation ecosystem in Jordan to provide an environment for entrepreneurs to build and grow their startups, and consequently create jobs. 
Business ecosystem design is a complex process. This research proposes a new method to reuse the principles and components of a successful regional venture creation ecosystem to implement a venture creation ecosystem in a different region. This will help individuals and organizations responsible for implementing venture creation ecosystems by reducing subjectivity, failure risk, efforts, and cost associated with implementing a new ecosystem.

Your participation in this research project would be conducted through an interview with the principal investigator (Abdallah Sunna) of approximately one hour in duration. The interview can be conducted remotely using Skype. The interview will be semi-structured, beginning with open-ended questions about the business ecosystem in Jordan and its stakeholders. I may also ask specific questions to establish further details.

This study has been approved by the Carleton University Research Ethics Board-B, Protocol \# (15-221) and the date of ethics expiration is on the 31 st of August 2016.

If you are interested in this study and would like to know more, please email the principal researcher at abdallahsunna@cmail.carleton.ca

Thank you for your consideration.

\section{B.2 Informed Consent:}

\section{Overview of the research project}

Lead To Win (http://www.leadtowin.ca) is a successful business ecosystem designed to be a job-creation engine in Canada's capital region. It supports entrepreneurs to create startups and employment in the region. This research reuses the principles and components of Lead to Win to propose a design for a venture creation ecosystem in Jordan to provide an environment for entrepreneurs to build and grow their startups, and consequently create jobs.

Business ecosystem design is a complex process. This research proposes a new method to reuse the principles and components of a successful regional venture creation ecosystem to implement a venture creation ecosystem in a different region. This will help individuals and organizations responsible for implementing venture creation ecosystems by reducing subjectivity, failure risk, efforts, and cost associated with implementing a new ecosystem.

Your participation in this research project would be conducted through an interview with the principal investigator (Abdallah Sunna) of approximately one hour in 
duration. The interview can be conducted remotely using Skype. The interview will be semi-structured, beginning with open-ended questions about the business ecosystem in Jordan and its stakeholders. I may also ask specific questions to establish further details. I will be taking notes about your answers on a text file during the interview. The text file will be stored on an encrypted flash drive which will remain in the custody of the research team for future use within five years, then it will be destroyed. You will be one of 5 to 20 interviewees for this phase of the research. When the research is done, it will be published by Carleton university as a master's thesis. The identities of participants will remain confidential, and responses will not be associated with particular participants.

During the interview, you may decline to answer any question, or stop the interview at any time. With your permission, you may be contacted again after the interview by the principal researcher, with follow-up questions, to review and discuss interim results of the study, or to confirm reported quotations. All of these follow-up activities are optional.

Participation is voluntary, and you may withdraw from the study at any time up to and including 30 calendar days after our interview by emailing me. If you choose to withdraw from the study, all records and any information that you have provided will be destroyed.

\section{Sample Questions}

General Questions:

- Please tell me about the startups' environment in Jordan?

- Please tell me about the parties currently involved in the startups' environment and what is in it for them?

Probing Questions:

- Who would be able to participate in opportunity reviews and provide feedback to entrepreneurs? What is in it for them?

- Who would be able to provide an entrepreneurial knowledge? What is in it for them?

- Who would be able to provide grants, seed, or venture capital funding to startups? What is in it for them?

- Who would be able to provide a work space for startups? What is in it for them?

\section{Anticipated Benefits}

Participants receive no financial remuneration. Although there are no direct benefits to you, your participation contributes to the body of knowledge on business 
ecosystems. At your request, I would be delighted to share with you the results of this study.

\section{Anticipated Risks}

There is minimal risk in participating. You may decline to answer any questions. The interview will be scheduled at a time convenient to you.

\section{Confidentiality and Anonymity}

Although participation in this study is not anonymous, the responses you provide will be strictly confidential. The principal researcher (me) and Professor Steven Muegge (my research supervisor) will have access to the data and notes. I will retain the data on an encrypted flash drive. If you withdraw from the study, I will destroy your data. Results will be reported only in summary form, and will not expose, in any way, your identity.

\section{Research Ethics}

This study has been approved by the Carleton University Research Ethics Board-B, Protocol \# (15-221) and the date of ethics expiration is on the 31 $1^{\text {st }}$ of August 2016.

For ethical concerns, please contact Dr. Shelley Brown, Chair, Carleton University Research Ethics Board-B (613-520-2600 ext.1505 or shelley.brown@carleton.ca); you may also contact the Carleton University Research Office at ethics@carleton.ca.

\section{Contact information}

Please contact me or Professor Muegge with any questions about this study:

Abdallah Sunna

Technology Innovation Management (TIM)

Department of Systems \& Computer Engineering

Carleton University

1125 Colonel By Drive

Ottawa, Ontario K1S 5B6

E-mail: abdallah.sunna@carleton.ca

Tel: 613-520-2600 Ext. 8659
Professor Steven Muegge

Technology Innovation Management (TIM)

Sprott School of Business

Carleton University

1125 Colonel By Drive

Ottawa, Ontario K1S 5B6

E-mail: smuegge@sce.carleton.ca

Tel: 613-520-2600 Ext. 6804 
Appendix C: Summary of responses from interviews with individuals that have knowledge about entrepreneurship in Jordan

Interview 1: (Academic Professor)

General notes:

- Attitude problem: people think your success is their failure

- If you organize a conference: people ask who will get the credit

- Individual benefit is number one

- Collaborative culture, win-win culture is not there

- There are technology restrictions in the country .. limitations on what technology is allowed and technology is not

- Intellectual property is a big problem and is not protected

Interview 2: (Startup employee)

General notes:

- No government support

- Entrepreneurship mainly exists because of high unemployment in Jordan

- Parties involved in entrepreneurship in Jordan include: Oasis500, King Abdullah II Center for Excellence (KACE), universities graduates (PSUT, JU, JUST)

- Technically, what entrepreneurs need is entrepreneurial knowledge

- Find what is in it for the person regardless the benefit to the organization 
Potential stakeholders and value propositions:

Keystone:

- KADDB

- Oasis500

- German Jordanian University, VP: public image

Reviewers:

- Young experienced entrepreneurs, VP: they want to help

- Engineering association

- Lawyers, VP: they need the networking for the future, they see the long term vision.

- Large company people: Zain CEO, Orange CEO, VP: to give back

Startups employees:

- New graduates

- Unemployed people

- Experienced people will not be interested to join

Donations:

- Abulhameed Shuman Institution, VP: there goal is to spread education .. they might have money and might be interested. 
Market intelligence:

- Maybe ministry of industry and trade, communication regulatory (TRC). Information only available for Jordanian market.

Bootcamps and workshops:

- Educational centers, VP: they get grants from the government

R\&D, E:

- Universities, VP: more students and money

Ecosystem fund:

- Ministry of industry and trade

- KADDB

Political support:

- Connect with ministers, VP: show his work and value, public image

Workspace:

- Universities

Employment grants:

- Labor ministry initiative for employment support (50:50) 


\section{Interview 3: (Entrepreneurial researcher)}

General notes:

- Lots of institutions are getting created. They have lots of PR agenda.

- There is a lack of consensus weather Oasis500 is functioning well or not.

- People build something physical for PR, such as incubators.

- QRCE has access to universities

- Finding real experts in Jordan to provide entrepreneurial knowledge is a challenge. They exist, but the population is small.

- It is a young ecosystem .. so the experts you find will be experts in the MENA area.

- Government programs that support entrepreneurs are pretty rare, and if they exist they are ineffective. These programs are obsolete.

- Pool of talents, there is a problem in the general willingness for a fresh graduate to work for a startup. There are lots of smart people. It is very rare to see entrepreneur go to university to recruit. There is a lack of credibility in universities.

- Lower your expectation about the ecosystem

Potential stakeholders and value propositions:

Investors:

- Dash ventures

- MENA investment 
- Silicon Badia

Entrepreneurial knowledge:

- INJAZ: teaches and spreads entrepreneurship to high schools and universities. it touches on social responsibilities of companies to make them to participate.

Interview 4: (Entrepreneur)

General notes:

- What you have in LTW is similar to Oasis500.

- Fadi Grandour has a partnership with a vertical incubators in China, which is perfect for hardware products.

- Endeavor: they are very weak, they put you in Endeavor network. It is good if you want to find a global market.

- No grants ..

- Jordan has a huge pool of talents in IT per capita

- Current challenges: Unfair competition with corporates, corruption problems. Social justice. Free access to market. If you get close to the business of a big business man, he can crush you. Monopolies. 
Potential stakeholders and value propositions:

Employment partners:

- Akhtaboot.com

- Bayt.com

R\&D grants:

- Mowgli Jordan

- Talal Abu-Ghazaleh Organization

Access to labs:

- iPark (PSUT)

Interview 5: (Serial Entrepreneur)

General notes:

- Any Jordanian can open a company within a day. The problem is not to open a company; the problem is to have a successful business.

- There is a lack in entrepreneurial knowledge ..

- There is a lack in complementary products, if you want to manufacture something, you have to do everything yourself ..

- There is no guidance or overall vision to what kind of business to enter or what kind of business is needed to complement what already exist.

- There is a need for an entity that study the existing needs of the market .. 
- In Jordan, we need to know what are our strengths and what are our weaknesses .. we can compete in specific kinds of business and we can't in others ..

- If the problem of accessing global market is solved, Jordan can compete in many industries .. for example plastic machine manufacturing ..

- The challenge of global market access is a mentality problem. How to think global?

- An example of a country with limited market and huge manufacturing capabilities is Italy. Their main market is the global market.

- We don't have a closed market strategy .. our markets are open, and the local manufacturers are not protected.

- Stakeholders, even if they have capabilities, they will not contribute unless you have a clear vision with clear plan.

Potential stakeholders and value propositions:

Keystone:

- Engineering association, VP: aligns with their vision

- Lots of human resources registered in the associations, mainly engineers

- They are very organized

- Lots of financial resources

- They have connections with Jordanian engineers all over the world 
- They are non-for profit; they think on a system level. Their goal is to serve and benefit Jordanian engineers.

Reviewers:

- Lawyer, VP: reputation, potential customers

- Accountants, VP: reputation, potential customers

- Business owners: to give back to community (mainly old people), reputation, potential opportunities to invest

- Entrepreneurs, VP: to give back to community (mainly old people), reputation, potential opportunities to invest

Grants:

- Engineering association

Workspace:

- Engineering association

Access to global market:

- Engineering association

Political support:

- Minister of industry 
Interview 6: (Entrepreneur, entrepreneurial activist)

General notes:

- Early stage funding from accelerators like oasis500 exists ..

- There is chicken and egg problem between investors and entrepreneurs

- I don't think the biggest challenge for entrepreneurs is early stage risk money. The biggest challenge is the pre-seed funding like grants, and R\&D funding .. this is the reason we don't have good enough startups ..

- Accelerators don't have real acceleration program .. they don't have real entrepreneurial knowledge ..

- QBIC (Qatar Business Incubation Centre) they have the most mature accelerator with entrepreneurial knowledge ..

- There is no proper training in IP, legal, financials, or marketing .. some publishers are trying to creating training arms ..

- We are not tapping to Arab entrepreneurs globally .. I think they will have an important role in the ecosystem ..

- Ecosystem funding .. usually foreign funding ..

- Access to global market: we have free trade agreements .. there is no systematic approach for accessing the global market ..

- Going global from day one is important .. however, we can start regional in MENA and GCC .. in these countries we have low hanging fruits .. 
Potential stakeholders and value propositions:

Investors:

- Two angle network are available in Jordan

Workspaces:

- iPark

- Grow (king hessian business park)

- Al Urdonia Lil Ebda

R\&D grants:

- SDRF research fund

- Arab Innovator Network

Opportunity assessment:

- Startup competitions: (QRCE, MIT enterprise forum, startup weekend)

Bootcamps \& workshops:

- Existing accelerators: ie. Oasis500

- Training with competitions

- Training with BDC (business development center) 
Interview 7: (Academic professor, entrepreneur)

General notes:

- Entrepreneurship in Jordan currently is bad, not sustained .. it is a way for people to get experience and then go to get jobs.

- Entrepreneurs goal is to flip .. build something .. sell it .. get experience .. and then get a job ..

- Some entrepreneurs start a company to have a record to be able to immigrate to US

- Current stakeholders: Universities (JUST, PSUT) .. government (ministry of labor), engineering association (they provide reference letters for engineers to get loans from banks), Oasis500, some investors (with the motivation to flip).

- The bottom line, is to have a big market like the US to support, invest, and acquire.

- If you want to make LTW in Jordan, you have to align your vision with the vision of the stakeholders.

- If there is a measure for the government to inform them how much percentage of unemployment they eliminated by investing some amount of money, it will be more convincing.

- Zain started an incubator to find good talents and generate entrepreneurial ideas.

- Entrepreneurship should be directed toward the nation problems like: water 
problem, unemployment problem.

- You have to identify the orchestrator (influencer) in every stakeholder, and align what you are doing with his personal goal.

- The mentality in Jordan is very short term. People are looking for very quick results. They are very result oriented. (even entrepreneurs). People care about personal benefits more than their organizations benefits.

- You have to convince stakeholders that they will get direct benefits by participation. Try to align the long term nation vision with the short personal benefits.

- In Jordan, we have a collectivist culture. You have to promote groups, rather than individuals.

Potential stakeholders and value propositions:

Keystone:

- Government (Power, water, industrial, natural resources, and labor ministries)

- Telecom industry (Zain), VP: find good talents and generate entrepreneurial ideas.

Market intelligence reports:

- There are websites, you subscribe them as an incubator, and they provide you with these reports. 
Workspace:

- Oasis500

- Engineering association

Investors:

- Investors from the gulf area.

Interview 8: (Entrepreneur)

Potential stakeholders and value propositions:

Keystone:

- German Jordan University, VP: possibility to move companies to Germany

- Zain, VP: PR, find new business opportunities

- Princess Sumaya University (PSUT), VP: to attract new students

Workspace:

- Talal Abu-Ghazaleh Organization, VP: To give back

- Aramex, VP: PR

Mentors, reviewers, coaches:

- Small business owners, VP: connections, PR

- Big business owners, VP: reputation, PR 
Access to labs and research:

- Universities: (PSUT, JUST, GJU), VP: ranking, financial stake, attract more students

Employment partners:

- Recruiting websites (Akhtoboot, bayt), VP: PR, More traffic

- Engineering Association, VP: aligns with their mission.

Legal and financial services:

- Talal Abu-Ghazaleh Organization, VP: To give back

Grants:

- QRCE, VP: to enhance the economy

- Zain, VP: PR, find new business opportunities

- Umnia, VP: PR, find new business opportunities

- Engineering Association, VP: aligns with their mission.

Investors:

- Fadi Ghandour (angel investor)

Investment assessments:

- Fadi Ghandour (angel investor), VP: find opportunities to invest; help youth. 
Employees for startups:

- Students, fresh graduates, VP: get experience to immigrate

Lead venture creation:

- Entrepreneurs, VP: create wealth, reputation

Table 15 summaries the responses from the eight interviewees from Jordan.

Table 15: Lead To Win-Jordan potential stakeholders - interviews responses

\begin{tabular}{|l|l|l|}
\hline Contributions & Potential Stakeholders & Value Propositions \\
\hline $\begin{array}{l}\text { Lead the creation of } \\
\text { ventures to become } \\
\text { leaders of the startup } \\
\text { community. }\end{array}$ & Entrepreneurs & $\begin{array}{l}\text { Wealth (build companies } \\
\text { to flip); experience to get } \\
\text { jobs; record to immigrate }\end{array}$ \\
\hline $\begin{array}{l}\text { Bring about and build the } \\
\text { ventures' offers; may } \\
\text { include employees, } \\
\text { directors, advisors, and } \\
\text { contactors who have a } \\
\text { direct financial stake in } \\
\text { the venture. }\end{array}$ & Students, fresh graduates & $\begin{array}{l}\text { Get experience to } \\
\text { immigrate }\end{array}$ \\
\hline - $\begin{array}{l}\text { Provide } \\
\text { entrepreneurial } \\
\text { knowledge, domain } \\
\text { knowledge or } \\
\text { managerial expertise } \\
\text { voluntarily; without } \\
\text { taking financial stakes }\end{array}$ & Young experienced & They like to help \\
\hline
\end{tabular}




\begin{tabular}{|c|c|c|}
\hline \multicolumn{3}{|l|}{$\begin{array}{l}\text { in the ventures they } \\
\text { assist. } \\
\text { - Provide reviewers for } \\
\text { opportunity } \\
\text { assessments. }\end{array}$} \\
\hline & $\begin{array}{l}\text { Service providers } \\
\text { (lawyers, accountants) }\end{array}$ & $\begin{array}{l}\text { Networking; find potential } \\
\text { customers; reputation }\end{array}$ \\
\hline & Large company people & Give back \\
\hline & $\begin{array}{l}\text { Old business owners \& } \\
\text { entrepreneurs }\end{array}$ & $\begin{array}{l}\text { Give back; reputation; } \\
\text { potential opportunities to } \\
\text { invest in }\end{array}$ \\
\hline & Education centers & $\begin{array}{l}\text { Money from the } \\
\text { government }\end{array}$ \\
\hline & $\begin{array}{l}\text { Existing accelerators } \\
\text { (have their own } \\
\text { bootcamps \& workshops) }\end{array}$ & \\
\hline & $\begin{array}{l}\text { INJAZ (has their own } \\
\text { workshops) }\end{array}$ & \\
\hline & $\begin{array}{l}\text { Business Development } \\
\text { Center (has their own } \\
\text { workshops) }\end{array}$ & \\
\hline & $\begin{array}{l}\text { Startup competitions } \\
\text { (have their own } \\
\text { workshops) }\end{array}$ & \\
\hline $\begin{array}{l}\text { Provide entrepreneurial } \\
\text { assets (workspace) }\end{array}$ & Universities & $\begin{array}{l}\text { Public image; brand; more } \\
\text { students and money }\end{array}$ \\
\hline & Engineering association & Aligns with their goals \\
\hline
\end{tabular}




\begin{tabular}{|l|l|l|}
\hline & $\begin{array}{l}\text { Existing incubators } \\
\text { (already have } \\
\text { workspaces) }\end{array}$ & Public image, brand \\
\hline $\begin{array}{l}\text { Talal Abu-Ghazaleh } \\
\text { Organization }\end{array}$ & To give back \\
\hline $\begin{array}{l}\text { Provide entrepreneurs, lab } \\
\text { access and research ready } \\
\text { to commercialize. }\end{array}$ & Aramex & PR \\
\hline $\begin{array}{l}\text { Provide implementers and } \\
\text { access to a network of } \\
\text { talents. }\end{array}$ & $\begin{array}{l}\text { Local employment } \\
\text { websites: akhtaboot.com / } \\
\text { bayt.com }\end{array}$ & $\begin{array}{l}\text { Public image; brand; more } \\
\text { students and money }\end{array}$ \\
\hline $\begin{array}{l}\text { Provide professional } \\
\text { services to ventures }\end{array}$ & $\begin{array}{l}\text { Service providers } \\
\text { (lawyers, accountants) }\end{array}$ & $\begin{array}{l}\text { Networking; find potential } \\
\text { customers; reputation }\end{array}$ \\
\hline $\begin{array}{l}\text { Establish operational } \\
\text { partnerships with } \\
\text { ventures; may include } \\
\text { channel to market } \\
\text { partners, supply chain } \\
\text { partners, and } \\
\text { manufacturing partners. }\end{array}$ & KADDB & Aligns with their goals \\
\hline $\begin{array}{l}\text { Provide products and } \\
\text { services that complement } \\
\text { the products or services of } \\
\text { ventures }\end{array}$ & $\begin{array}{l}\text { Provide grants and other } \\
\text { assistance to ventures }\end{array}$ & Engineering association \\
\hline & & \\
\hline
\end{tabular}




\begin{tabular}{|c|c|c|}
\hline & Endeavor & Aligns with their goals \\
\hline & $\begin{array}{l}\text { Talal Abu-Ghazaleh } \\
\text { Organization }\end{array}$ & To give back \\
\hline & $\begin{array}{l}\text { Abd Al Hamid Shoman } \\
\text { Foundation }\end{array}$ & \\
\hline & Mowgli Jordan & \\
\hline & SDRF research fund & \\
\hline & Arab Innovator Network & \\
\hline & Ministry of Labor & \\
\hline Provide fund to & KADDB & Public image; brand \\
\hline & $\begin{array}{l}\text { Ministry of Industry and } \\
\text { Trade }\end{array}$ & \\
\hline $\begin{array}{l}\text { Try and buy new products } \\
\text { or services at the earliest } \\
\text { stages of discontinuous } \\
\text { change, providing early } \\
\text { feedback and building } \\
\text { legitimacy for the venture. }\end{array}$ & & \\
\hline $\begin{array}{l}\text { Provide capital to grow } \\
\text { ventures. }\end{array}$ & DASH Ventures & \\
\hline & MENA Investment & \\
\hline
\end{tabular}




\begin{tabular}{|c|c|c|}
\hline & Silicon Badia & \\
\hline & Oasis500 & \\
\hline & Angel networks & \\
\hline & $\begin{array}{l}\text { Investors from the Gulf } \\
\text { area }\end{array}$ & \\
\hline $\begin{array}{l}\text { Provides vision, } \\
\text { leadership, and } \\
\text { governance for the } \\
\text { ecosystem. } \\
\text { - } \text { Maintains the } \\
\text { ecosystem health. } \\
\text { - Recruits members, } \\
\text { build audience, and } \\
\text { extends reach. } \\
\text { - } \text { Brand the ecosystem. } \\
\text { - Run and organize } \\
\text { LTW-Jordan } \\
\text { operations and } \\
\text { activities. }\end{array}$ & KADDB & Public image; brand \\
\hline & Universities & $\begin{array}{l}\text { Public image; brand; more } \\
\text { students and money }\end{array}$ \\
\hline & Engineering association & Aligns with their goals \\
\hline & Telecom companies & $\begin{array}{l}\text { Find talents; generate } \\
\text { entrepreneurial ideas; PR }\end{array}$ \\
\hline & Existing accelerators & \\
\hline & Ministries & \\
\hline
\end{tabular}




\begin{tabular}{|l|l|l|}
\hline Access to global market & Endeavor & Aligns with their goals \\
\hline & Engineering association & Aligns with their goals \\
\hline $\begin{array}{l}\text { Identify ready for } \\
\text { investment opportunities } \\
\text { and provide feedback and } \\
\text { advice to entrepreneurs } \\
\text { about their investment } \\
\text { pitches. }\end{array}$ & Arab entrepreneurs & \\
\hline
\end{tabular}




\section{Appendix D: Lessons learned about entrepreneurship in Jordan}

- The business ecosystem in Jordan is still young, and there are lots of rooms for improvement.

- There are lots of initiatives that support entrepreneurship in Jordan, however, there is not yet a fully consistent initiative.

- Generating revenue is a big challenge for entrepreneurs in Jordan because of the lack in entrepreneurial knowledge.

- There are several initiatives that provide early stage capital and venture capital, however, there is still lack of investments. In addition, entrepreneurs don't understand how investors think and what they are looking for.

- Expanding to new countries is a big challenge for entrepreneurs, especially with the small market size in Jordan. This challenge is associated with finding strategic partners, and some legal issues related to expansion.

- There are challenges for entrepreneurs in finding talents to build teams, retaining the talents, and paying salaries. 


\section{Appendix E: Lessons learned about launching multi-sided platforms}

- Multi-sided platforms should select suitable ignition tactics to overcome the common chicken-and-egg problem.

- The ignition tactics of some multi-sided platforms are sequential entry, zigzag, targeting aggregators, offering standalone value, targeting niche industries, targeting marquee stakeholders, building small communities, reducing participation risks, and ensuring compatibility.

- Sequential entry: onboard one side first, then onboard the others. This tactic works best in the case of non-positive indirect network effect.

- Basic zig-zag: build participation on each side incrementally. Start with small number of stakeholders on each side, then move to other sides to convince them to join.

- Attract large number of stakeholders at once: target either physical or online aggregators where you can find large number of intended stakeholders in one place.

- Stand-alone value: add a service or a feature that makes the platform valuable for a stakeholder even if no body else joins.

- Start with industry niche: find a niche that is valuable to your stakeholders.

- Build small social groups: build groups around shared goals or interests.

- Target marquee stakeholders: these stakeholders are usually known to other stakeholders, and when they join they provide high credibility to the platform. 
- Reduce joining risks: reduce commitments, especially financial commitment.

- Ensure compatibility: offer just enough compatibility with legacy systems to attract stakeholders. Anticipate resistance. 